\section{Pacific Northwest}

National Laboratory

Operated by Battelle for the

U.S. Department of Energy

\title{
The Columbia River Protection Supplemental Technologies Quality Assurance Project Plan
}

N. J. Fix

January 2007

Prepared for the U.S. Department of Energy under Contract DE-AC05-76RL01830 


\title{
DISCLAIMER
}

This report was prepared as an account of work sponsored by an agency of the United States Government. Reference herein to any specific commercial product, process, or service by trade name, trademark, manufacturer, or otherwise does not necessarily constitute or imply its endorsement, recommendation, or favoring by the United States Government or any agency thereof, or Battelle Memorial Institute.

\author{
PACIFIC NORTHWEST NATIONAL LABORATORY \\ operated by \\ BATTELLE \\ for the \\ UNITED STATES DEPARTMENT OF ENERGY \\ under Contract DE-AC05-76RL01830
}

\author{
Printed in the United States of America \\ Available to DOE and DOE contractors from the \\ Office of Scientific and Technical Information, P.O. Box 62, Oak Ridge, TN 37831; \\ prices available from (615) 576-8401. \\ Available to the public from the National Technical Information Service, \\ U.S. Department of Commerce, 5285 Port Royal Rd., Springfield, VA 22161
}




\section{The Columbia River Protection Supplemental Technologies Quality Assurance Project Plan}

January 2007

Prepared for

the U.S. Department of Energy

under Contract DE-AC05-76RL01830

Pacific Northwest National Laboratory

Richland, Washington 99352 



\section{Summary}

The U.S. Department of Energy (DOE) has conducted interim groundwater remedial activities on the Hanford Site since the mid-1990s for several groundwater contamination plumes. DOE established the Columbia River Protection Supplemental Technologies Project (Technologies Project) in 2006 to evaluate alternative treatment technologies. The objectives for the technology project are as follows: develop a 300 Area polyphosphate treatability test to immobilize uranium, design and test infiltration of a phosphate/apatite technology for Sr-90 at 100-N, perform carbon tetrachloride and chloroform attenuation parameter studies, perform vadose zone chromium characterization and geochemistry studies, perform in situ biostimulation of chromium studies for a reducing barrier at 100-D, and perform a treatability test for phytoremediation for Sr-90 at 100-N.

This document provides the quality assurance guidelines that will be followed by the Technologies Project. This Quality Assurance Project Plan is based on the quality assurance requirements of DOE Order 414.1C, Quality Assurance, and 10 CFR 830, Subpart A--Quality Assurance Requirements as delineated in Pacific Northwest National Laboratory’s Standards-Based Management System. In addition, the technology project is subject to the Environmental Protection Agency (EPA) Requirements for Quality Assurance Project Plans (EPA/240/B-01/003, QA/R-5). The Hanford Analytical Services Quality Assurance Requirements Documents (HASQARD, DOE/RL-96-68) apply to portions of this

project and to the subcontractors. HASQARD requirements are discussed within applicable sections of this plan. 


\section{Contents}

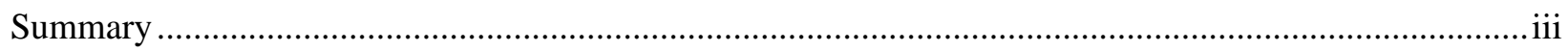

1.0 Quality Assurance Project Plan Distribution ........................................................................... 1

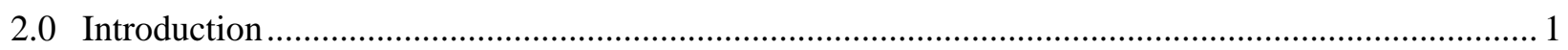

2.1 Title

2.2 Client

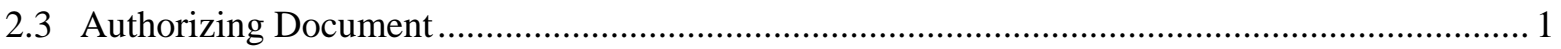

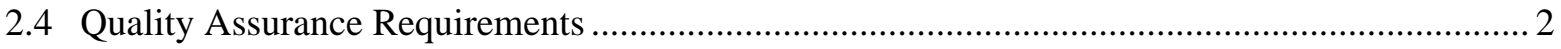

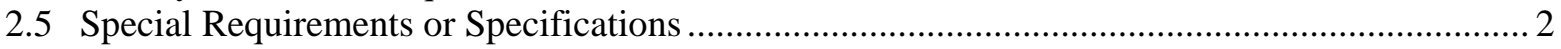

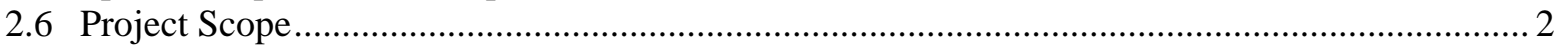

2.7 Change Control (Scope, Schedule, Budget) …........................................................................... 3

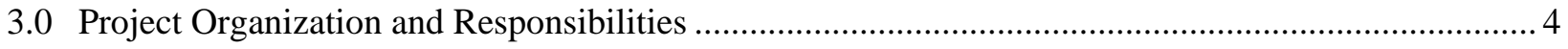

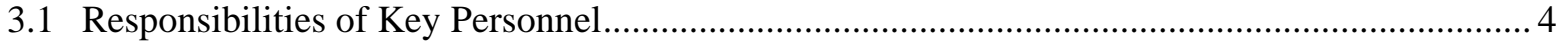

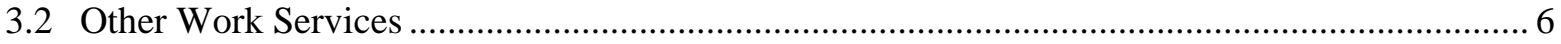

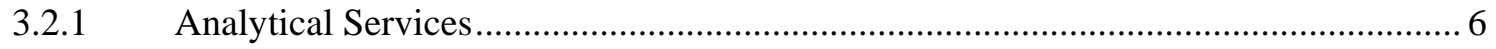

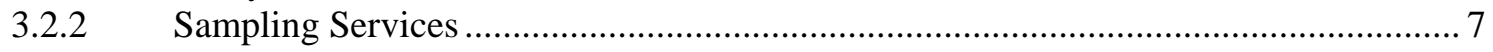

3.2.3 Well Drilling, Sampling, and Construction Services ............................................ 7

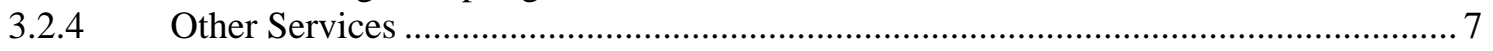

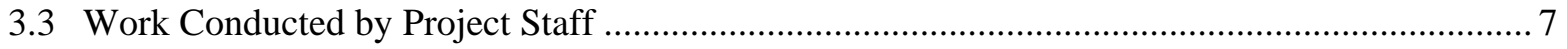

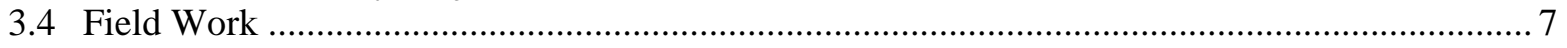

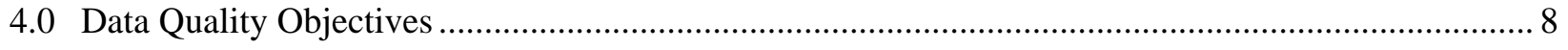

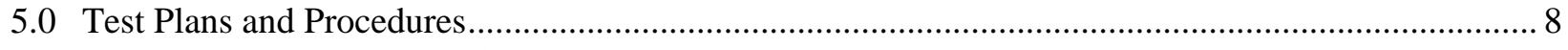

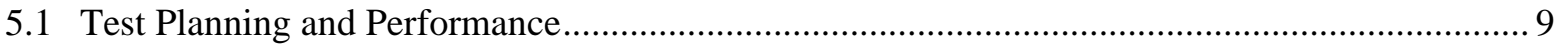

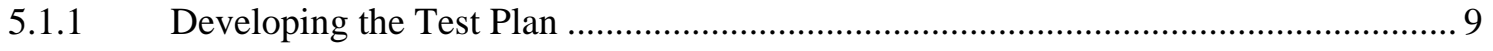

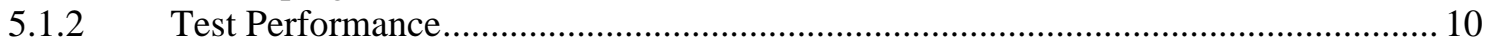

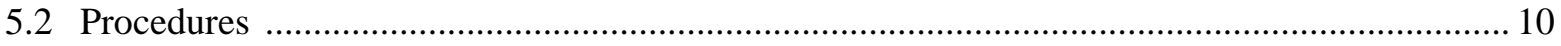

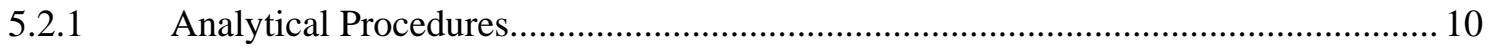

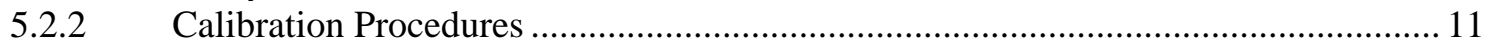

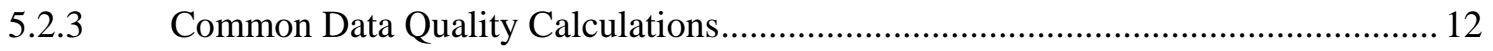

5.2.4 Well Drilling and Construction Procedures .......................................................... 12

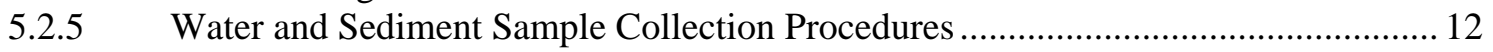

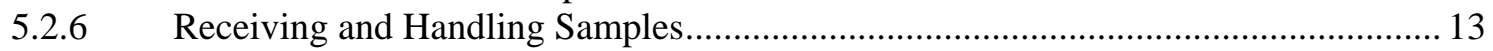

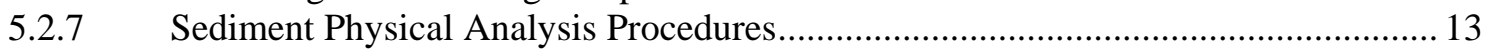

5.2.8 Sediment Core Analysis Procedures …................................................................. 13

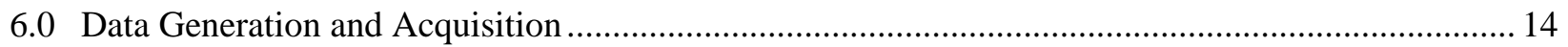

6.1 Sampling Process Design (Experimental Design) ............................................................ 14

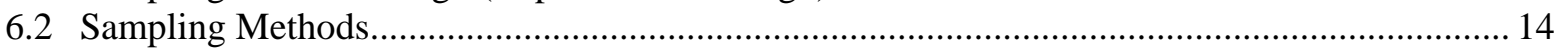

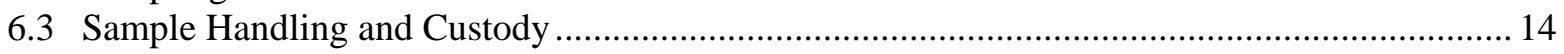

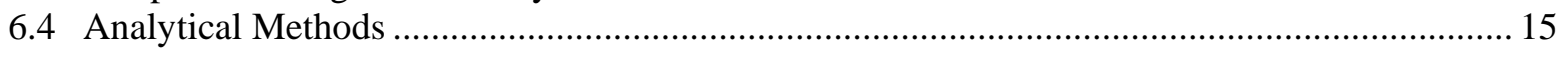

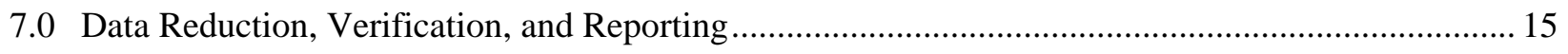

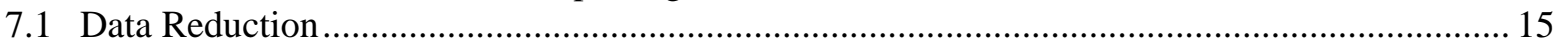

7.2 Sample Data and Tracking for Sediment and Other Media Samples ...................................... 16

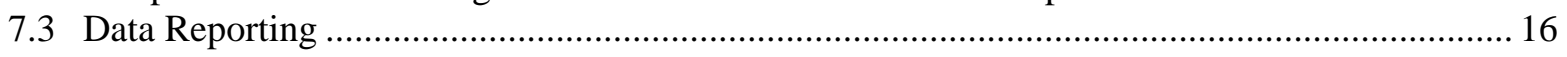

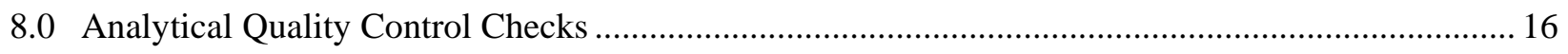




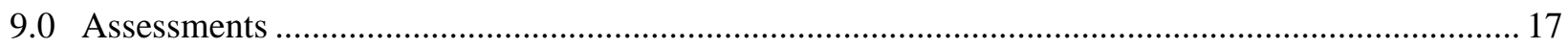

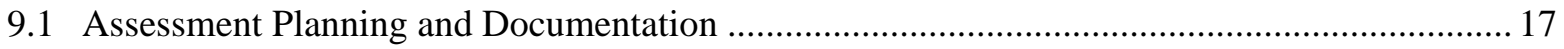

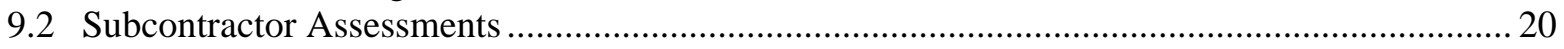

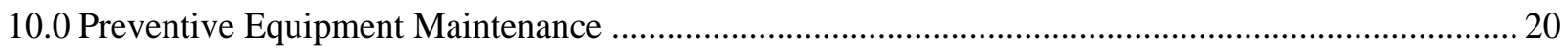

11.0 Specific Routine Procedures Used to Assess Data Precision, Accuracy, and Completeness .............. 20

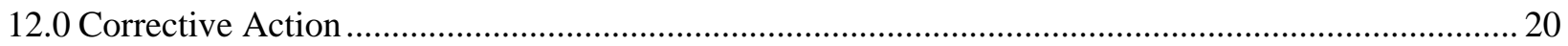

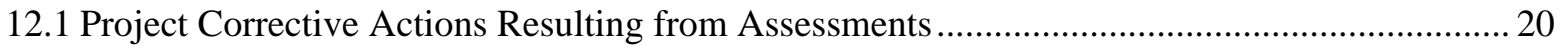

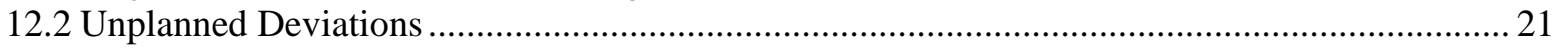

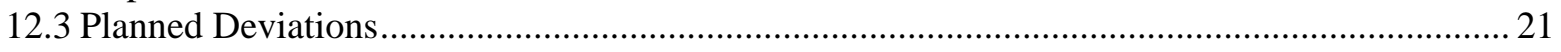

12.4 Measuring and Test Equipment Calibration Discrepancies .................................................... 21

13.0 Quality Assurance Reports to Management..................................................................................... 22

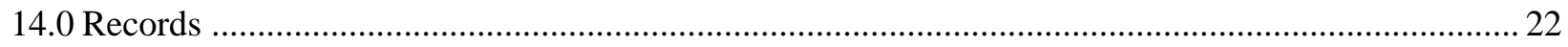

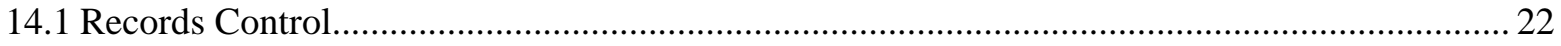

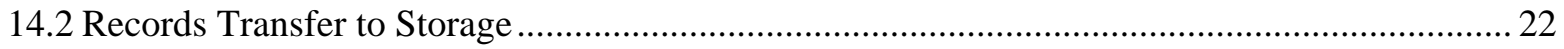

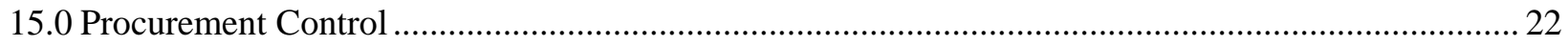

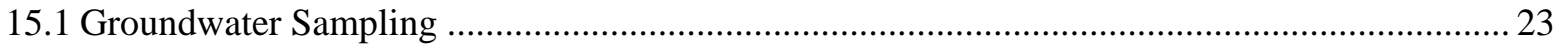

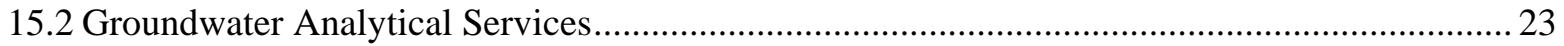

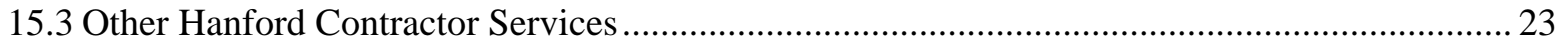

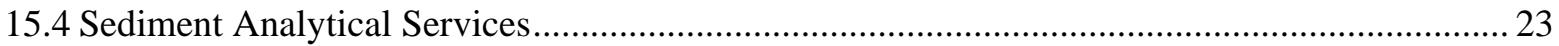

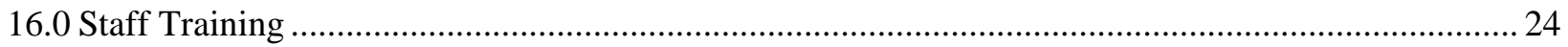

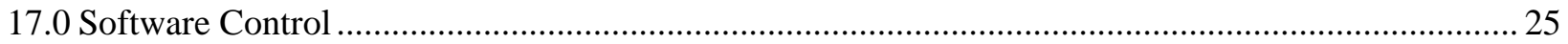

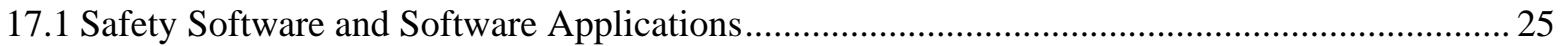

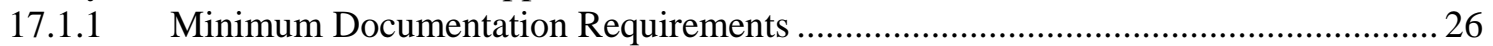

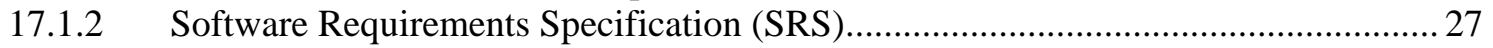

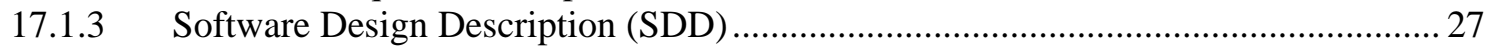

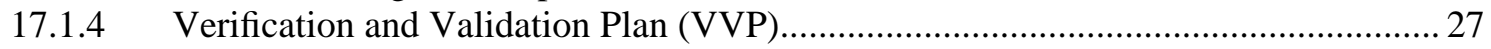

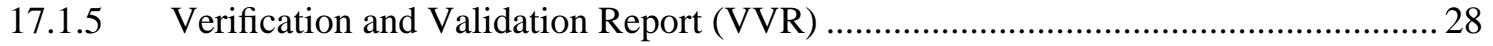

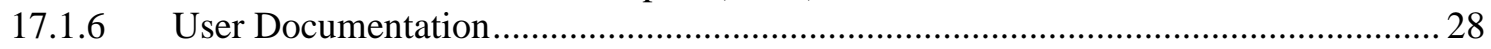

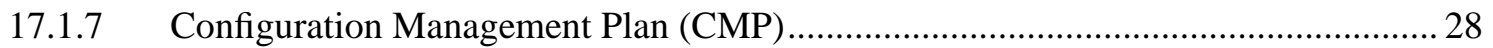

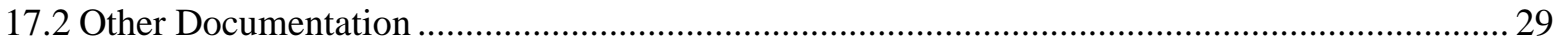

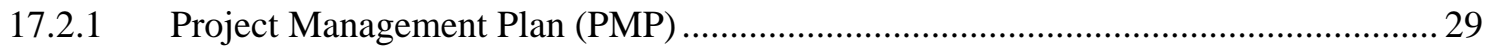

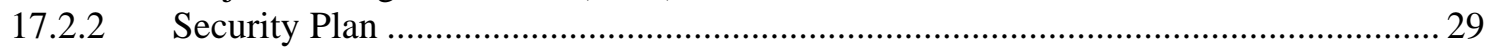

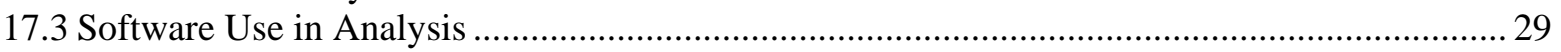

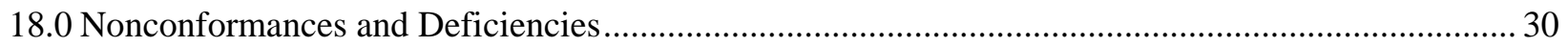

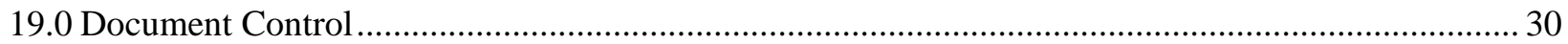

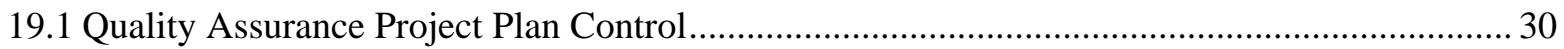

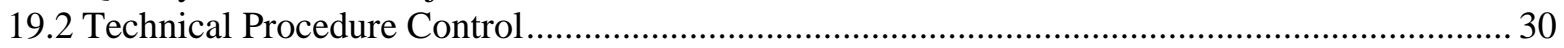

19.3 Administrative Procedure /Instruction Preparation and Control ............................................... 31

19.4 Test Plans and Other Work Documents .................................................................................. 31

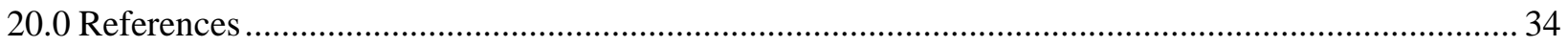

Appendix A - The Columbia River Protection Supplemental Technologies Project

Quality Control Plan ................................................................................................................ A.1

Appendix B - Additional Analyses and Measurements to be Employed for the Treatability Studies ........B.1 
Appendix C - Experimental and Modeling Procedures for Subsurface Science

Representative Sites Task

C.1

\section{Figures}

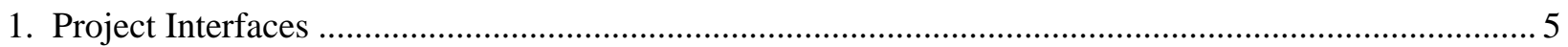

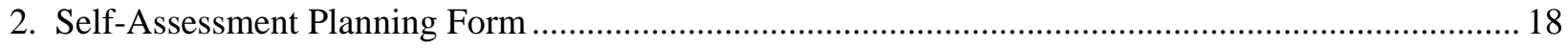

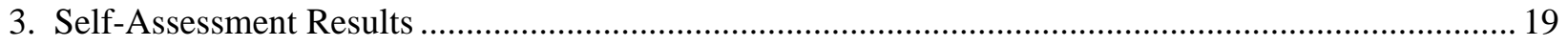

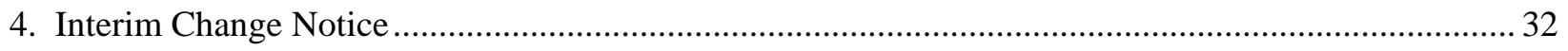

\section{Tables}

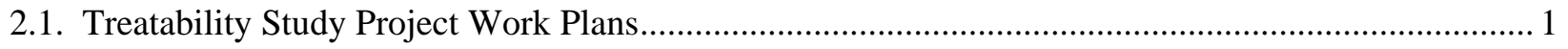




\subsection{Quality Assurance Project Plan Distribution}

Pacific Northwest National Laboratory (PNNL) Document Control will distribute this Quality Assurance Project Plan (QAPjP) internally to PNNL, the U.S. Department of Energy (DOE) Reading Room and Technical Library. The project manager will determine the distribution list. Also, the QAPjP will be published in accordance with the Standards-Based Management System (SBMS) subject area, Publishing Scientific and Technical Information (PNNL 2002a).

\subsection{Introduction}

\subsection{Title}

The Columbia River Protection Supplemental Technologies Quality Assurance Project Plan.

\subsection{Client}

U.S. Department of Energy, Richland Operations Office, Richland, Washington.

\subsection{Authorizing Document}

Work has been authorized by specified multi-year project work plans as shown in Table 2.1.

Table 2.1. Treatability Study Project Work Plans

\begin{tabular}{|c|c|c|}
\hline Project Number & Project Work Plan Title & Author(s) \\
\hline PNNL-SA-49953 & $\begin{array}{l}\text { 100-N Area Strontium-90 Treatability } \\
\text { Demonstration Project: Phytoremediation Along } \\
\text { the 100-N Columbia River Riparian Zone }\end{array}$ & CC Ainsworth \\
\hline PNNL-SA-49954 & $\begin{array}{l}300 \text { Area Uranium Plume Treatability } \\
\text { Demonstration Project: Uranium Stabilization } \\
\text { Through Polyphosphate Injection }\end{array}$ & $\begin{array}{l}\text { VR Vermeul, D.M Wellman, TG } \\
\text { Naymik, MJ Nimmons }\end{array}$ \\
\hline PNNL-SA-50071 & $\begin{array}{l}\text { Sequestration of Strontium-90 Subsruface } \\
\text { Contamination in the Hanford 100-N Area by } \\
\text { Surface Infiltration of an Apatite Solution }\end{array}$ & JE Szecsody \\
\hline PNNL-SA-50369 & $\begin{array}{l}\text { Hanford 100-D Area Treatability Demonstration: } \\
\text { In Situ Biostimulation for a Reducing Barrier }\end{array}$ & $\begin{array}{l}\text { JS Fruchter, MJ Truex, VR } \\
\text { Vermeul, PE Long }\end{array}$ \\
\hline PNNL-SA-50254 & $\begin{array}{l}\text { Chromium Vadose Zone Characterization and } \\
\text { Geochemistry }\end{array}$ & CC Ainsworth \\
\hline PNNL-SA-51843 & $\begin{array}{l}\text { Carbon Tetrachloride and Chloroform } \\
\text { Attenuation Parameter Studies: Heterogeneous } \\
\text { Hydrolytic Reactions }\end{array}$ & $\begin{array}{l}\text { JE Amonette, MJ Truex, JS } \\
\text { Fruchter }\end{array}$ \\
\hline
\end{tabular}




\subsection{Quality Assurance Requirements}

The Columbia River Protection Supplemental Technologies Project's Quality Assurance Program is based on the QA requirements of DOE Order 414.1C, Quality Assurance, and 10 CFR 830, Subpart A-Quality Assurance Requirements as delineated in PNNL's SBMS. The project is subject to the Environmental Protection Agency (EPA) Requirements for Quality Assurance Project Plans (EPA/240/B01/003, QA/R-5) as required by the Tri-Party Agreement (TPA; Ecology et al. 1989). The project is subject to the Price Anderson Amendments Act (PAAA) as defined in the PNNL PAAA Program and implemented through SBMS (See Price-Anderson Amendments Act, [PNNL 2006a]). Additionally, the Technologies Project has determined that the Hanford Analytical Services Quality Assurance Requirements Documents (HASQARD, DOE/RL-96-68) apply to portions of this project and to the subcontractors. HASQARD requirements are discussed within applicable sections of this plan. The PNNL document for implementing HASQARD is Conducting Analytical Work in Support of Regulatory Programs (CAWSRP) located at http://etd.pnl.gov/docs/conducting-work/index.stm.

\subsection{Special Requirements or Specifications}

DOE Orders 435.1, Radioactive Waste Management; 5400.5, Radiation Protection of the Public and Environment; and 450.1, Environmental Protection Program, apply to the treatability studies to ensure that activities related to radioactive materials and samples are protective of human health and the environmental and stewardship requirements of PNNL.

The modeling projects shall comply with the software requirements as specified in the PNNL's SBMS Safety Software (PNNL 2006d) subject area. Specific safety software requirements are described in Section 17.

\subsection{Project Scope}

DOE has conducted interim groundwater remediation activities on the Hanford Site since the mid1990s for several groundwater contamination plumes. DOE established the Columbia River Protection Supplemental Technologies Project (herein after referred to as the Technologies Project) in 2006 to evaluate alternative treatment technologies. The objectives for the Technologies Project are as follows: develop a 300 Area polyphosphate treatability test to immobilize uranium; design and test infiltration of a phosphate/apatite technology for strontium (Sr)-90 at 100-N Area; and perform a test for phytoremediation for Sr-90 at 100-N Area. Additional objectives include laboratory evaluation of carbon tetrachloride and chloroform attenuation parameters, evaluation of the geochemistry of chromium in the Hanford vadose zone, and evaluation of chromium degradation through in situ biostimulation using polylactate injection at 100-D Area. These six objectives comprise the six project tasks within the technology project.

The 300 Area polyphosphate treatability test will evaluate the efficacy of using polyphosphate injections to treat uranium-contaminated groundwater in situ. Data obtained from this study will be used to develop implementation cost estimates, identify implementation challenges, and investigate the ability of the technology to meet remedial objectives. This information will be used in the 300-FF-5 Phase III feasibility study during final evaluation of remedial alternatives. 
The test of the 100-N Area phosphate/apatite technology for Sr-90 will inject an apatite-forming solution, which should result in sufficient removal capacity of Sr-90 for approximately 10 years followed by higher concentration injections to develop further capacity. Because most (50\% to $70 \%$ ) of the Sr-90 contamination is in the shallow, variably saturated Hanford formation, the most efficient means of treating this zone may be surface infiltration of the apatite-forming solution, but there has been no development of this technology for vadose zone application.

The phytoremediation test for Sr-90 will (1) determine the most efficient fertilization method for coyote willow that will generate the greatest biomass possible while protecting the Columbia River from excess nutrient runoff; and (2) demonstrate the efficacy of using coyote willow as a Sr-90 phytoremediation tool along the riparian zone associated with the 100-N Area of the Hanford Site. The initial effort will be in a "cold zone" outside of the contaminated area; follow-on work, if funded, will be conducted within a contaminated area.

The carbon tetrachloride/chloroform study will determine (1) the neutral and base-catalyzed homogeneous hydrolysis rates for chloroform under near-ambient temperatures, (2) the impact and mechanisms of representative Hanford mineral surfaces on the hydrolysis of carbon tetrachloride at nearambient temperatures, and (3) the impact and mechanisms of representative Hanford mineral surfaces on the neutral and base-catalyzed hydrolysis of chloroform at near-ambient temperatures.

The chromium geochemistry project will (1) determine the leaching characteristics of Cr(VI) from contaminated sediments collected from 100 Area spill sites, (2) elucidate possible $\mathrm{Cr}(\mathrm{VI})$ mineral and/or chemical associations that may be responsible for $\mathrm{Cr}(\mathrm{VI})$ retention in the Hanford Site 100 Areas through the use of (i) macroscopic solubility studies and (ii) microscale characterization of contaminated sediments, and (3) from these data construct a conceptual model of $\mathrm{Cr}(\mathrm{VI})$ geochemistry in the Hanford 100 Area vadose zone.

The 100-D Area in situ biostimulation technology is intended to provide supplemental treatment upgradient of the In Situ Redox Manipulation (ISRM) barrier by directly treating chromium and other oxidizing species in groundwater (i.e., nitrate and dissolved oxygen). This thereby increases the longevity of the ISRM barrier and protects the ecological receptors and human health at the river boundary.

\subsection{Change Control (Scope, Schedule, Budget)}

The project scope, schedule, and budget baseline are compiled, tracked, and reported using a project control system in accordance with DOE direction.

Changes in work scope, schedule, or budget may be necessary during the year. Changes may be requested of subcontractors by PNNL that will result in a change to the statements of work (SOWs) due to revisions of work scope, schedule, and/or budget. These changes will be documented in revisions or addendums to the existing SOWs and a PNNL Subcontracts Supplement Form shall be completed.

Administrative changes requested of subcontractors that are approved by Task Leaders may be made by verbal or electronic message authorization. Written documentation of the verbal changes and electronic messages should be maintained in the permanent project files. These changes may only be made if technical work scope and budget are not affected significantly. 


\subsection{Project Organization and Responsibilities}

Line authority, quality assurance authority and support within PNNL, and client interfaces are shown organizationally in Figure 1. The responsibilities of key PNNL personnel are summarized in Section 3.1. Changes to organizational/interface structures shown in Figure 1 that do not reflect a change in the overall scope of the activities or a change of requirements will not require a QAPjP revision and will be incorporated into the next required revision of the QAPJP.

\subsection{Responsibilities of Key Personnel}

- Project Manager - provides overall direction to task managers and project personnel within PNNL necessary to accomplish project objectives; coordinates and executes project controls associated with scope, schedule, and budget baselines; reports on project status; assures that the project is staffed with technically qualified personnel; serves as primary client interface to assure that customer expectations are met in terms of quality, cost, and schedule; assures the QAPjP is implemented.

- Technology Task Leaders — oversees task-specific planning, control, communications, and progress reporting; prepares scope, resource needs, cost baseline, and deliverables; assures quality and timeliness of the work, in accordance to plans, policies, and procedures; provides monthly reports; interfaces with DOE, other contractors, subcontractors, and other Task Leaders.

- Technology Principle Investigators - provides task-specific technical plans, communications, and progress reporting to the Task Leader; prepares technical details of the task plan; assures technical quality of the work; supports the Task Leader to assure work is performed on schedule, within budget, and in accordance to plans, policies, and procedures; assigns and directs work of project staff; interfaces with DOE, other contractors, subcontractors, and other Investigators.

- Project Quality Engineer - provides guidance and direction to Project Manager, Task Leads, and project staff within PNNL on PNNL QA Program requirements; performs assessments to assure quality of the work; develops, updates, and approves QAPjP; reviews and approves appropriate work plans and procedures.

- Other Project Staff - assures technical quality of the work and that it is performed on schedule, within budget, and in accordance to plans, policies, and procedures; reports concerns such as unsafe conditions and stops work as necessary. 


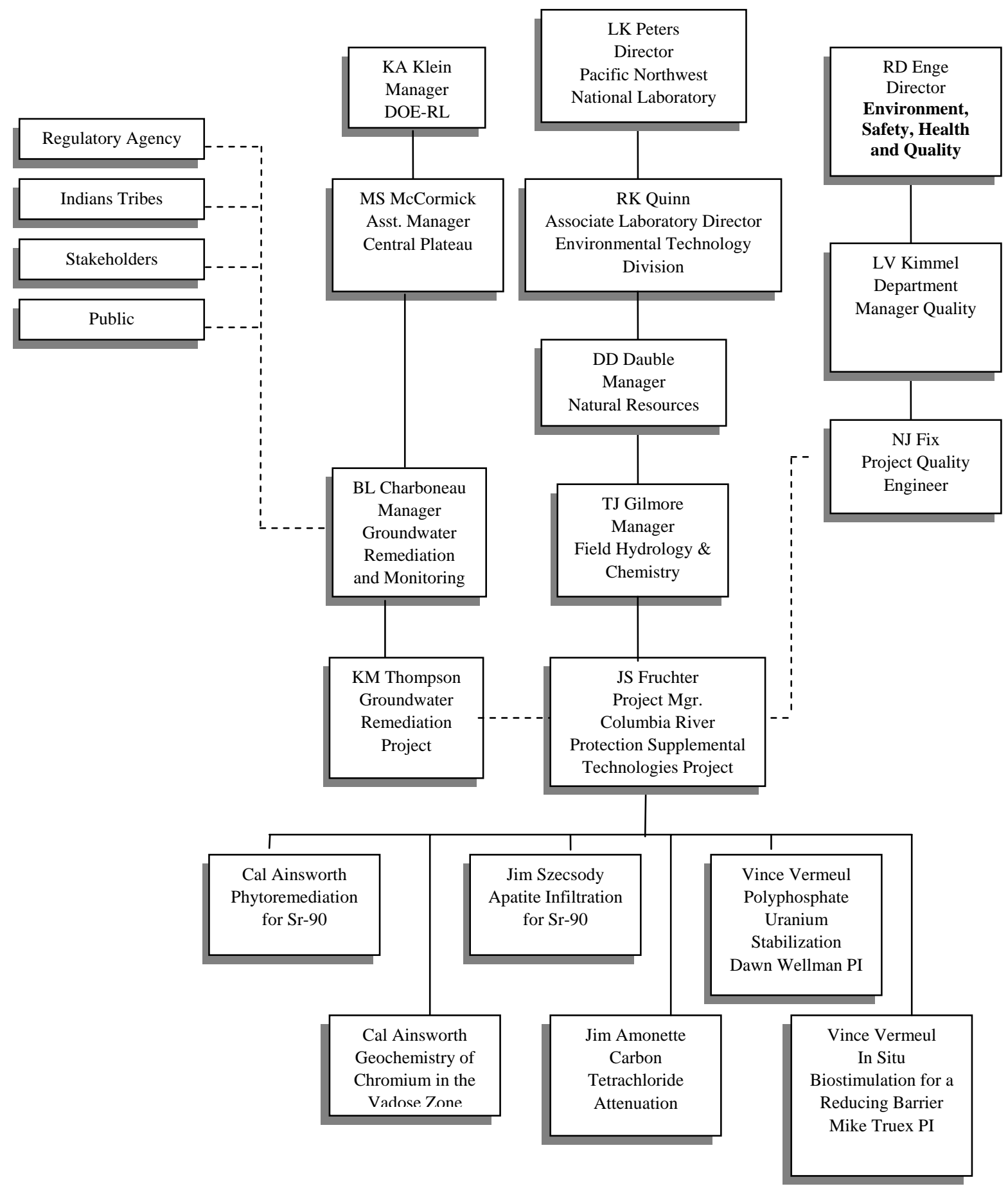

Figure 1. Project Interfaces 


\subsection{Other Work Services}

Other work services for various portions of project work will be through the purchasing process. General scope of work, work requirements, specifications, and quality assurance requirements are communicated via a contracting mechanism to various subcontractors (see Section 14.0). Statements of Work (SOWs) to subcontractors used for groundwater and sediment sampling and analysis will require compliance with the HASQARD (DOE/RL-96-68) and/or the EPA Requirements for Quality Assurance Project Plans (EPA/240/B-01/003, QA/R-5), and will specify requirements to be achieved by appropriate quality documents. The SOW will include instructions for inspecting/accepting supplies and consumables used for this project.

Subcontracts for drilling, sediment sampling, groundwater sampling, and associated support activities will include the following:

- Fluor Hanford, Inc. (FHI) - performs routine groundwater sampling and water-level measurements, purge water containment and disposal, radiological control technician support, and miscellaneous solid waste disposal.

- FHI also provides drilling, sediment and water sample collection related to drilling, and well construction services.

Subcontracts for analytical laboratory services will include the following:

- Severn Trent Laboratories

- Other subcontractors - may provide civil surveys, special analytical services, or other services.

\subsubsection{Analytical Services}

The analytical laboratories including commercial, on-site, and other DOE national laboratories are responsible for preparing data reports that summarize the results of analyses and detailed data packages that include the following:

- Sample receipt and tracking documentation, including identification of the organization and individuals performing the analysis; names and signatures of the responsible analysts; sample holding time requirements; references to applicable chain-of-custody procedures; and dates of sample receipt, extraction (if applicable), and analysis.

- Quality control data, as appropriate for the methods used, including (as applicable) matrix spike/matrix spike duplicate data, recovery percentages, precision and accuracy data, laboratory blank data, and identification of any nonconformance that may have affected the laboratory's measurement system during the time period in which the analysis was performed.

- Analytical results or data deliverables, including reduced data and identification of data qualifiers and contractually defined reporting comments. 
These requirements as well as QA and technical requirements are specified in the SOW to the analytical laboratories. Also, the requirements for the hard copy and electronic data received from the analytical laboratories are specified in respective analytical subcontractor SOWs.

\subsubsection{Sampling Services}

The sampling organization is responsible for (1) obtaining the samples; (2) delivering samples to the laboratory; and (3) delivering completed sampling and water-level paperwork to PNNL. Activities associated with the sample collection, sample handling, sample labeling, and custody of the samples in the field shall be consistent with the SOW.

\subsubsection{Well Drilling, Sampling, and Construction Services}

FHI provides well-drilling and construction subcontractors and oversight on the Hanford Site. FHI is responsible for (1) well drilling design specifications and contract management, (2) site preparation and documentation requirements, (3) sediment and water sample collection during drilling, (4) support of hydrologic tests conducted during drilling, and (5) well construction, development, and sample pump installation. Well construction will meet the requirements of WAC 173-160. Well drilling and construction, sediment and water sampling, testing support, and associated quality requirements will be specified in the SOW to FHI. FHI may subcontract work activities provided the requirements in the SOW and the FHI QA Program are met by subcontractor(s).

\subsubsection{Other Services}

Other subcontracted services received from FHI or other Hanford Site contractors may include construction of fences and enclosures, geophysical logging, etc.

\subsection{Work Conducted by Project Staff}

Analytical activities conducted by the project staff in support of the technology project shall be conducted in accordance with written standard operating procedures. Field measurements will be conducted in accordance with in-house operating procedures. The project staff members are responsible for preparing data reports that summarize the results of analyses, quality control data for the methods used, and identification of data qualifiers. The results and raw data will be included in the project records.

Project staff will perform sampling and measurements according to written and approved test plans (Section 5.1), written procedures, or other written direction.

\subsection{Field Work}

Field work is executed by the treatability study projects. Prior to executing field work, projectspecific test plans are developed, as described in Section 5. If supplemental information or individual parameters are needed to perform a test, a test instruction will be developed. The test instruction shall be reviewed by a technical reviewer. 
Field work associated with task activities is conducted in accordance with the Surface Environmental Surveillance Procedures Manual (PNL-MA-580, Rev. 4). The following procedures in PNL-MA-580 are used:

- Section 4.1 - Grab Samples

- Section 4.6 - Sampling Columbia River Riverbank Springs

- Section 4.8 - Specific Conductance

- Section $4.9-\mathrm{pH}$ Measurement

- Section 4.10 - Water Filtration

- $\quad$ Section 8.1 - Trip Sheets.

A specific procedure for sampling aquifer tubes is undergoing final review and will be included in the Procedures for Ground-Water Investigation Manual (PNL-MA-567) upon completion.

\subsection{Data Quality Objectives}

The QA objectives for measurements generally applicable to technology investigations under the purview of this QAPjP are primarily related to (1) the definition of appropriate methods and analytical precision and accuracy appropriate for chemical analysis of the analytes of interest; and (2) the definition of methods and limits and values for physical measurements associated with the investigation (e.g., column tests). Discussions of aqueous sample analytical objectives and analytical methods with corresponding target values for detection limits, precision, and accuracy are provided in the Groundwater Performance Assessment Project Quality Assurance Plan Appendix (QC Plan contained in PNNL-15014, current revision), the Environmental Sciences Laboratory QA Plan (QAP ESL, Rev. 0), individual test plans, and/or test procedures. The sediment analytical objectives and analytical methods with corresponding target values for detection limits, precision, and accuracy are provided in the Environmental Sciences Laboratory QA Plan, individual test plans, and/or test procedures. Other measurement objectives and methods with corresponding target values for detection limits, precision, and accuracy (as applicable) are provided in the specific work plans and/or the SOW for such activities. Specific data quality needs for individual investigations that are different than the requirements established herein shall be addressed within individual work plans. Other measurement considerations, accuracy requirements, units, and data recording and reporting protocols for instruments supporting stratigraphic characterization, aquifer testing, and other types of field investigations shall be as specified in the applicable plans and/or procedures.

\subsection{Test Plans and Procedures}

Test plans and procedures are used to ensure that activities affecting quality are performed consistently and correctly. Test plans are prepared by PNNL staff to conduct a single experiment or test as identified below. Formal procedures will be developed for quality affecting work activities that are routinely performed. 


\subsection{Test Planning and Performance}

Test plans will be used to document a single or related set of experiments or tests (e.g., hydrologic field tests, vertical sampling) of work activity.

\subsubsection{Developing the Test Plan}

The test plan shall contain the following information:

- A title and/or number including date or revision.

- Dated signatures of the Preparer, Technical Lead, Project Manager or Task Lead, and Quality Representative.

- Individual page identification (page __ of __).

The content of each test plan will depend on the scope of the test. The following is a brief description of mandatory and optional items to be considered in the preparation of the test plan:

- Purpose/Description (mandatory) - Provide a short narrative on the purpose of the experiment/test/activity.

Example: The purpose of this test is to provide hydrologic property data at polyphosphate treatability injection test wells.

- Prerequisites (mandatory) - List items, conditions, or other concerns that must be satisfied prior to beginning the test.

Example: Prior to beginning the work activity, the staff must complete special training on other plans or procedures that will be used in conjunction with the test plan, special handling or storage requirements, special access or permits, and required records that need to be generated as the result of the work activity.

- Safety (mandatory) - Describe the hazards associated with the work such as physical agents (e.g., temperature, pressure, noise, electrical); hazardous environments (e.g., confined spaces, remote locations, heat/cold stress); and hazardous materials (e.g., flammables, corrosives, highly toxic, carcinogens). Describe the methods used to mitigate the hazards that were identified (e.g., personal protective equipment, time periods away from the hazard, alarms, location of nearest aid station).

- Materials and Equipment (optional) - List the materials and equipment that are necessary to complete the work.

- Measuring and Test Equipment (mandatory) - List the equipment that will be used to make the measurements; include the calibration requirements, system checks, and quality control checks in this section or in the work instructions section of the test plan. 
- Pretest Verification (mandatory) - Determine if certain items of a test require verification prior to their use and indicate how the verification will be done.

+Example: A tracer solution containing $\mathrm{Br}$ will be used throughout the test and the initial concentration shall be known. The solution shall be measured by the calibrated probe (as described above) and the concentration shall be recorded prior to injection.

- Documentation and Reporting (mandatory) - Describe where the data collected during the test should be documented (e.g., field record forms, laboratory record books, entered into a computer, downloaded from computer to hardcopy) or entered into HEIS. Additionally, describe what will be reported, to whom, and the due date(s).

- Work Instructions (mandatory) - Provide step-by-step instructions and/or non-sequential instructions (whichever is more appropriate to the activity). Each step or instruction shall be as simple as possible but with sufficient detail so that individuals experienced in the technology or activity involved can easily understand. The following types of information should be considered for inclusion: administrative control hold points (i.e., where safety, quality, radiological, or other approvals or actions are required before proceeding); cautions that indicate potentially hazardous situations which, if not avoided, may result in death, injury, or damage to facilities or equipment; and notes that call attention to supplemental information that assist the user in making decisions or improving work performance.

\subsubsection{Test Performance}

Tests will be performed in accordance with the test plans, which shall be available at the work location. The Technical Lead is responsible for assuring that the current version is used to perform the work.

If changes to the test plan are required during the execution of the work, the Technical Lead shall document the deviation and the justification or rationale for the change.

\subsection{Procedures}

Procedures will be developed in accordance with SBMS subject area, Procedures, Permits, and Other Work Instructions (PNNL 2004). Project staff will perform scheduling, data verification, data processing, and data management as described in Section 6 and by following the applicable internal technical procedures or instructions.

\subsubsection{Analytical Procedures}

The specific work plans and/or test plans identify the constituents to be analyzed. As applicable, a PNNL internal procedure generates the sampling package (e.g., chain-of-custody form), which identifies the analytical methods, sample identification, etc. on the chain-of-custody form. The chain-of-custody form and samples are provided to the appropriate analytical laboratory. Administrative quality assurance processes and procedures (e.g., chain of custody, custody logs, sample handling, storage and disposal, training) will be required of the onsite and offsite analytical laboratories and will be specified in the SOW. The analytical methods required may be contained within the following references: 
- Test Methods for Evaluating Solid Waste (EPA/SW-846, as amended)

- Methods for Chemical Analysis of Water and Wastes (EPA-600/4-79-020)

- Methods for the Determination of Organic Compounds in Drinking Water (EPA-600/4-88-039)

- Prescribed Procedures for Measurement of Radioactivity in Drinking Water (EPA-600/4-80-032)

- Procedures for Radiochemical Analysis of Nuclear Reactor Aqueous Solutions (EPA-R4-73-014)

- Radiochemical Analytical Procedures for Analysis of Environmental Samples (EMSL-LV-0539-17).

Many radiochemical methods have not been standardized, but the procedures are documented in the laboratory-specific standard operating procedures. Aqueous sample chemical and radiological analytical methods and requirements for constituents are specified by the SOW, work plan, or other written direction. Most potential chemical constituents to be analyzed are provided in the Groundwater Performance Assessment Project Quality Assurance Plan Appendix (QC Plan; see PNNL-15014, current revision) and/or the Environmental Sciences Laboratory QA Plan (QAP ESL, Rev. 0). Sediment and other media constituents to be analyzed and corresponding analytical methods and procedures will be passed on to the analytical laboratory by a SOW, work plan, or other written direction.

Method detection limits (MDLs) shall be determined for all non-radiochemical methods required by the project. The laboratory provides MDL study results to PNNL as specified in the SOW. Required detection limits for radiochemical methods are provided in the SOW, work plan, or other written direction.

Technical procedures not previously documented will be developed and used as described in CAWSRP, Section 7, Procedures. If supplemental information or individual parameters are needed to perform a test, a test instruction will be developed. The test instruction shall be reviewed by a technical reviewer and must include the following information:

- A unique numerical designation

- Revision number

- Title

- Effective date

- Instructions - operating parameters and specific test run information such as sample size and /or composition, temperature, $\mathrm{pH}$, test duration, etc.

- Reference to controlling procedure or test plan

- Approval by author

- When well-established methods (e.g., ASTM, Soil Science Society of America, or EPA) are used, a PNNL cover page will not be provided unless there is a deviation from the established method.

Appendix B lists additional analyses and measurements with the respective procedures, methods, and other relevant information.

\subsubsection{Calibration Procedures}

The requirements for calibrating field and analytical laboratory instruments and maintaining traceability to national or international standard (e.g., National Institute of Standards and Technology) are in accordance with Test Methods for Evaluating Solid Waste: Physical/Chemical Methods, EPA/SW-846 and HASQARD (DOE/RL-96-68). These requirements are passed to the subcontractors by a SOW. 
PNNL will periodically assess the use and effectiveness of procedures and systems for calibration of equipment with the subcontractors.

Measuring and test equipment (M\&TE) used by PNNL staff to collect quality affecting data that are calibrated by the user (Category 2 M\&TE) or by an approved external or internal source (Category 1 M\&TE) will be in accordance with SBMS subject area, Calibration (PNNL 2005b). Upon receiving calibrated equipment, staff must review the documentation for acceptability, verify the proper operation of the M\&TE, and check the calibration label.

Measuring and test equipment shall be controlled as described in CAWSRP, Section 4, Instrument Calibration, and in accordance with the SBMS subject area Calibration (PNNL 2005b). Externally calibrated M\&TE such as balances will be calibrated in accordance with manufacturer's tolerances unless other control limits are specified and justification is provided.

Data sheets and log book entries will be used to document pipette performance checks. Calibration reports and other calibration data will be maintained as project records.

Quality control requirements are described in CAWSRP, Section 5, Quality Control, and in Appendix C of this QAMP. A few exceptions to CAWSRP requirements are considered necessary for the project, as described in the following paragraphs.

\subsubsection{Common Data Quality Calculations}

Data quality parameters of precision, accuracy, measures of agreement, detection limits/sensitivity, and uncertainty will be calculated per the formulas in CAWSRP, Section 6, in the exhibit Calculations for Assessing Data Quality. For radiochemistry analyses, the minimum detectable activity (MDA) is reported as the detection limit.

CAWSRP Exhibit "Calculations for Assessing Data Quality" - Control charting is a tool used to monitor an ongoing/continuous process where there are sufficient data points to perform a representative statistical evaluation. The analyses performed within this project are performed as a research function in which instrumental operating parameters may be changed to accomplish many different objectives. The frequency of instrumental operating changes does not allow accumulation of sufficient data points to properly utilize control charting as a statistical analysis tool. In lieu of control charts, instrument performance is monitored daily by the use of fixed control limits.

\subsubsection{Well Drilling and Construction Procedures}

A SOW to FHI specifies well drilling, characterization (aquifer and sediment sampling, etc.), and construction requirements. These activities will be performed to FHI procedures and/or to subcontractor procedures (e.g., geophysical logging). FHI Health and Safety, QA procedures, and waste management procedures will be followed during the drilling activity.

\subsubsection{Water and Sediment Sample Collection Procedures}

Groundwater sampling of a routine nature will be done by Fluor Hanford Nuclear Chemical Operators (NCOs). Quality requirements for sampling activities, including requirements for procedures, 
containers, transport, storage, chain of custody, and record requirements, are specified in a SOW. Nonroutine sample collection may be performed by PNNL staff in order to meet specific conditions or requirements.

To verify that samples of known quality are obtained, FHI and PNNL staff will be required to use controlled procedures based on standard methods for groundwater sampling whenever possible. Assessments will be performed by PNNL to further assure that procedures are followed to maintain sample quality and integrity (see Section 8).

Sediment and water samples collected during drilling will be collected by or under the direction of FHI, and in accordance with FHI or subcontractor procedures. The quality requirements for sampling activities, including chain of custody, storage, and records requirements are specified in the Statement of Work (or well data sheet). Scheduling sample bottle preparation, conducting sample analysis, and preparing associated paperwork are conducted by PNNL in accordance with PNNL internal procedures.

\subsubsection{Receiving and Handling Samples}

Directions for sample receipt, handling, and storage are provided in CAWSRP, Section 3, Receiving and Handling Samples, and in the SBMS subject area Sample Handling, Archival, and Disposal (PNNL 2006c).

Chain of custody for samples will be documented using a chain of custody form. An example of a chain of custody form is provided as an exhibit in CAWSRP. Each PNNL facility is a secured area, restricted to authorized personnel only. Chain of custody will be documented for moving samples from one facility to another, but not for moving samples within a secured facility.

The samples to be received from other PNNL groups are materials from various field investigations. Documentation of unique sample and sub-sample identifications will be maintained for samples received from other PNNL groups and for other samples generated from tests conducted by the project. The documentation may consist of entries in Laboratory Record Books or data sheets.

Disposition of unused materials may include returning the material to another group at PNNL, the client or disposal at PNNL. Material returned to the client will be documented by a chain of custody. Material disposed of at PNNL will be documented by standard waste paperwork (forms).

\subsubsection{Sediment Physical Analysis Procedures}

Sediment physical analyses including moisture content, particle-size distribution, hydraulic conductivity, water retention, water content, bulk density, particle density, and matric potential will be performed as directed in the test plan by PNNL staff. These procedures are contained in the internal Procedures for Groundwater Investigations (PNL-MA-567).

\subsubsection{Sediment Core Analysis Procedures}

Sediment core analyses and column experiments will be performed by PNNL staff as directed in the test plan. Procedures are contained in the individual test plans, which will either provide a procedure or reference an existing procedure. 


\subsection{Data Generation and Acquisition}

\subsection{Sampling Process Design (Experimental Design)}

The experimental data generation and data collection designs for each of the treatability study projects are described in the individual work plans and sampling and analysis plans.

Routine sampling processes used to support the treatability studies will be in accordance with the waste management area sampling design, based on the regulatory requirements (e.g., RCRA or CERCLA) and applying the Data Quality Objectives Process in accordance with Guidance on Systematic Planning Using the Data Quality Objectives Process (EPA/240/B-06/001 [QA/G-4]). A description of these processes will be included in sampling and analysis plans along with the number of samples, when to sample, number of sample locations, number of quality control samples (field replicates, etc.), analysis methods and quality control criteria, and the groundwater level measurements.

\subsection{Sampling Methods}

The procedures for collecting samples and identifying the sampling methods and equipment, including any implementation requirements, sample preservation requirements, decontamination procedures, and materials needed for projects involving physical sampling, are described in the treatability study-specific work plans and procedures. Specific performance requirements for the methods are also described. If a failure in the sampling or measurement system occurs, documentation of and recovery from the failure will be documented in the project-specific laboratory record book. The treatability study principle investigator is responsible for ensuring that the corrective action is effective and documented.

The preparation and decontamination of sampling equipment, including the disposal of decontamination by-products; the selection and preparation of sample containers, sample volumes, and preservation methods; and maximum holding times to sample extraction and/or analysis are also treatability study topic-specific and will be managed in accordance with SW-846 or PNNL-specific procedures, as applicable. Waste generated as a result of the activities will be handled in accordance with SBMS subject areas, Treatability Studies (PNNL 1999) and Waste, Managing (PNNL 2006e).

Field sample collection, if applicable, will be done by Fluor Hanford Nuclear Chemical Operators (NCOs) under the direction of FHI and specific procedures. PNNL will prepare, integrate, and coordinate sample collection schedules and constituent analysis of groundwater samples in accordance with monitoring plans and a specific procedure. The paperwork and instructions provided to the field personnel will include Sample Authorization Forms, Chain of Custody forms, labels, and the Groundwater Sample Reports. PNNL will track, oversee, and interface with the sampling organization to ensure that the work is completed as specified.

\subsection{Sample Handling and Custody}

Water samples will be collected by NCOs under the direction of FH and in accordance with FH procedures. Custody of the samples in the field and receipt at the laboratory will be documented on the 
Chain of Custody forms in accordance with FH procedures. Also, shipping and transporting of the samples will be handled by the NCOs under the direction of FH and in accordance with FH procedures.

\subsection{Analytical Methods}

The sampling and analysis plan for each site will identify the sample constituents and the analytical method. The sampling package (e.g., chain-of-custody form, groundwater sampling report) will be generated by an internal procedure, which identifies the analytical methods, sample identification, etc. on the chain-of-custody form. The chain-of-custody form and samples are provided to the appropriate analytical laboratory. The analytical methods required may be contained within the following references:

- Test Methods for Evaluating Solid Waste (EPA/SW-846, as amended)

- Methods for Chemical Analysis of Water and Wastes (EPA-600/4-79-020)

- Methods for the Determination of Organic Compounds in Drinking Water (EPA-600/4-88-039)

- Prescribed Procedures for Measurement of Radioactivity in Drinking Water (EPA-600/4-80-032)

- Procedures for Radiochemical Analysis of Nuclear Reactor Aqueous Solutions (EPA-R4-73-014)

- Radiochemical Analytical Procedures for Analysis of Environmental Samples (EMSL-LV-0539-17).

Many radiochemical methods have not been standardized, but the procedures are documented in the laboratory-specific standard operating procedures. These analytical methods requirements will be passed on to the analytical laboratory in their SOW.

Potential chemical constituents to be analyzed for, specific analytes of interest, and the corresponding standard analytical methods on which the primary analytical laboratory bases its procedures will be displayed in the Groundwater Monitoring and Reporting QA Plan. The contract to the analytical laboratories, which is administered by FHI, specifies the use of these procedures.

Method detection limits (MDLs) shall be determined for all non-radiochemical methods required by the project. Water MDLs shall be determined in accordance with 40 CFR 136, Appendix B -- Definition and Procedure for the Determination of the Method Detection Limit-Revision 1.11. The laboratory will provide the MDL study results to the PNNL Point of Contact when new MDLs have been determined. Required detection limits for radiochemical methods are provided in the analytical laboratory contract.

\subsection{Data Reduction, Verification, and Reporting}

\subsection{Data Reduction}

Data measured during technology project investigations are compiled, evaluated, and documented as described below. Samples and associated analyses will be scheduled and tracked to ensure successful sample collection. Selected data may be loaded into the Hanford Environmental Information System (HEIS) Database, as identified in the respective test plan. Tools in use by the Groundwater Performance Assessment Project may be utilized as appropriate for the data objectives and use.

Verification of analytical data provided by subcontracted laboratories is performed in accordance with the Groundwater Performance Assessment Project Quality Assurance Plan (PNNL-15014, current 
revision), as appropriate. Results are reviewed to ensure the reliability and validity of the field and laboratory measurements based on accuracy, precision, and detection limits. Representativeness, completeness, and comparability may also be evaluated for overall quality. These parameters are evaluated through laboratory QC checks, replicate sampling and analyses, analysis of blind standards and blanks, and interlaboratory comparison. Acceptance criteria are established for each of these parameters in the Groundwater Performance Assessment Project Quality Assurance Plan Appendix (QC Plan), the Environmental Sciences Laboratory QA Plan (QAP ESL, Rev. 0), and/or in specific test plans. When a parameter is outside the criteria, corrective actions are taken to prevent a future occurrence and any data impacted is appropriately flagged. If appropriate, the review will take into account results of the quality control evaluation as defined in the internal procedure QC-5, Groundwater Data Validation and Process (see PNL-MA-567), and results of the review are documented as stated in the test plan.

When the data review identifies suspect data, those data are investigated to establish whether they reflect true conditions or an error. A RDR is initiated in accordance with the procedure DA-3, Data Review Procedure (see PNL-MA-567). If there are any limitations noted on the data, a flag will be added to the data in HEIS.

\subsection{Sample Data and Tracking for Sediment and Other Media Samples}

Completed data packages for sediment and other media samples will be verified by PNNL personnel prior to loading into HEIS (if applicable) or reported. Verification will consist of verifying required deliverables for completeness, required QC results, chain of custody forms, and case narrative that describes any issues related to the sample analyses. Verification may also include evaluating and qualifying results based on holding times, method blanks, matrix spikes, laboratory control samples, laboratory duplicates, and chemical and tracer recoveries, as appropriate to the methods used. No other verification/validation or calculation checks will be performed.

\subsection{Data Reporting}

Interpretative data, test results, and reports will be released through the information release process in accordance with the Publishing Scientific and Technical Information (PNNL 2002a) SBMS subject area.

\subsection{Analytical Quality Control Checks}

Analytical Quality Control (QC) checks are performed on internal and external samples. A summary of QC check samples is outlined in the Groundwater Performance Assessment Project Quality Assurance Plan Appendix (QC Plan; PNNL-15014, current revision), the Environmental Sciences Laboratory QA Plan (QAP ESL, revision 0), and/or in specific test plans. Internal QC data are generated when the analytical laboratory prepares QC samples to monitor the quality of their analyses.

The QC activities needed for sampling, laboratory (internal and external) and field analysis, and measurement techniques will be defined in the appropriate treatability study test plans. For each required QC activity, the associated method, acceptance criteria, and corrective action will be listed. Also required for the field and laboratory QC activities are blanks, duplicates, matrix spikes, laboratory control samples, 
and surrogates in the plans. The project-specific QA Plans also identify the procedure, formulae, or references for calculating the percent recovery, bias, and precision.

\subsection{Assessments}

Assessments are performed to gather results that can be evaluated to measure the effectiveness of the quality systems and processes implemented by the project. Assessments will be performed periodically during the year. The following types of assessments may be used at varying frequencies during the year:

- Management self assessment — an assessment performed by those immediately responsible for overseeing and/or performing the work to establish whether policies, practices, and procedures are adequate for ensuring results needed.

- Management independent assessment — an assessment performed by an individual or group independent of the work performed to ensure that policies, practices, and procedures are adequate for obtaining the needed.

- Technical independent assessment — an assessment performed by an individual or group technically competent to do the work but independent of the work being performed to assure qualitative and quantitative aspects of the work are accomplished according to documented specifications.

\subsection{Assessment Planning and Documentation}

Assessment planning is done by the project management team (including Project Manager, Task Leaders, PI, and appropriate staff) in consultation with the project Quality Engineer. Assessments are in accordance with the SBMS subject area, Planning, Assessment, and Analysis, Section 2 Performance Assessment (PNNL 2005c). The assessor plans the assessment on a Self-Assessment Planning Form (Figure 2) where the scope of the assessment, topic, and supporting references are documented on the plan. A unique identification number is assigned to the plan and entered on an Assessment Log Sheet.

Results of assessments will be documented on a Self-Assessment Results form (Figure 3). The corrective action and action owner will be documented on the assessment report. The Task Manager will assign the action owners, and the Project Manager will prioritize the corrective actions. An action item log will be maintained by the project Quality Engineer to track and close out actions, and to finally verify the corrective actions. The Project Manager will sign the assessment report when the corrective actions have been closed. The assessment plan and report will distributed to the appropriate Task Managers, Project Manager, and project records. 


\begin{tabular}{|l|l|}
\hline Scope \& Location: (General: Maintenance, Operations, & $\begin{array}{l}\text { I.D. Number: (ATS Number or other Unique Tracking } \\
\text { Number) }\end{array}$ \\
\hline Topic: (Describe what will be assessed) & Date: (Date planning form is prepared) \\
\hline $\begin{array}{l}\text { References: (Cite Source Documents for Performance Expectations i.e., Regulation, Environmental Permit, DOE Order, } \\
\text { A-Manual, Standards Based Management System [SBMS], Requirements, Procedures and Guidelines [RPG]). }\end{array}$ \\
\hline
\end{tabular}

\section{Performance Expectations}

Criteria developed from Source Documents that will be applied throughout the assessment. Each criteria/expectation will have the reference enclosed in parenthesis at the end of the criteria/expectation statement (e.g., DOE Order 5480.19, SBMS, RPG). Performance expectations should be limited to six maximum to allow the assessment to remain focused. Additional Planning Forms can be completed to expand the scope of a particular assessment.

1.

2.

3.

4.

5.

6.

Procedure: (Perform the following as applicable for the assessment)

Review assessment planning form

- Review applicable procedure/requirements. (references)

- Conduct performance tests and data validation.

- Observe the activity controlled by the procedure.

- Interview appropriate personnel about requirements and practices.

- Record observations based on comparison to plan.

- Document the results after receiving final information on the Self-Assessment Results form.

\begin{tabular}{|ll}
\hline Basics for the [ ] Planned [ ] Lessons Learned \\
Assessment: [ ] Responsive [ ] Other
\end{tabular}

Work Package Number (optional):

Assessment Requestor/Authorizing Person:

\section{Assessor(s):}

Figure 2. Self-Assessment Planning Form 


\begin{tabular}{|c|c|}
\hline Assessor: & I.D. Number: \\
\hline Assessment Location: & Date: (Date assessment performed) \\
\hline \multicolumn{2}{|c|}{$\begin{array}{c}\text { Results } \\
\text { (Related to Associated Performance Expectations) }\end{array}$} \\
\hline \multicolumn{2}{|c|}{$\begin{array}{l}\text { (Use additional pages if necessary.) Concise and objective statements are the goal. Subjective comments may be added at } \\
\text { the end and must be based upon a series of facts that supports the comments. Include strengths and improvement } \\
\text { opportunities. Include date the information is obtained and list of line manager or points-of-contact during assessment. }\end{array}$} \\
\hline \multicolumn{2}{|l|}{ Summary } \\
\hline \multicolumn{2}{|l|}{1.} \\
\hline \multicolumn{2}{|l|}{2.} \\
\hline \multicolumn{2}{|l|}{3.} \\
\hline \multicolumn{2}{|l|}{4.} \\
\hline 5. & \\
\hline
\end{tabular}

\section{Subsequent Actions}

(Related to Associated Results)

\begin{tabular}{|l|l|l|}
\hline \multicolumn{1}{|c|}{ Assigned Action } & \multicolumn{1}{|c|}{ Action Owner } & Due Date \\
\hline 1. & & \\
\hline 2. & & \\
\hline 3. & & Date: \\
\hline 4. & & \\
\hline Actions Assigned By: & & \\
\hline $\begin{array}{l}\text { Completion (To be signed by Lead Assessor when assessment is completed.) } \\
\text { Signature: } \\
\text { Date: }\end{array}$ \\
\hline $\begin{array}{l}\text { Completion (To be signed by Manager when assessment is completed and all actions have been entered into ATS) } \\
\text { Signature: } \\
\text { Date: }\end{array}$
\end{tabular}

Figure 3. Self-Assessment Results 


\subsection{Subcontractor Assessments}

If PNNL passes work on to subcontractors, periodic assessments of analytical subcontractors are performed as an oversight function or prior to contract award in accordance with the internal acquisition quality procedures. Provisions are made in the SOW for oversight assessment activities to be performed as necessary.

The results of all subcontractors' assessments (including surveillances and audits) will be made available to project and line management, individuals contacted, and the client as requested. The corrective action tracking, corrective action, and closure response will be in accordance with the internal acquisition quality procedures. The official assessment report files and responses (audits and surveillances) are maintained in the PNNL Suppliers History File by the Quality Assurance Services group.

Periodic assessments of the well drilling and construction, drilling and sampling-related activities, and the analytical laboratory may also be performed in accordance with the requirements discussed above.

\subsection{Preventive Equipment Maintenance}

Subcontracted organizations will be required to implement preventive maintenance on their equipment to mitigate the possibility of down time affecting cost and schedule. This will be specified in the SOW to the respective organizations.

\subsection{Specific Routine Procedures Used to Assess Data Precision, Accuracy, and Completeness}

The evaluation of laboratory precision, accuracy, and completeness is accomplished during the verification process performed upon receipt of data (see Section 7 of this plan).

\subsection{Corrective Action}

\subsection{Project Corrective Actions Resulting from Assessments}

As part of the continuous improvement processes initiated by the project management team, assessments will be tracked and improvement actions identified and prioritized. The Assessment Tracking System (ATS) is the process used by this master project for tracking and managing assessments, including determining Conditions and the development of actions. ATS supports the identification, control, and correction of items, services, and processes that do not meet established requirements. The SBMS Assessment Management (PNNL 2005a) subject area documents this corrective action management process for handling and documenting events and assessments, including those that must be tracked in ATS such as formal project reviews or audits performed by the client or 
their representative; management-initiated assessments; etc. If immediate corrective action is required, the quality problem will be directly entered into the ATS and actions taken as specified in Section 12.2.

\subsection{Unplanned Deviations}

Corrective action must be initiated by the Project Manager or cognizant Task Leader when unplanned deviations from procedural, contractual, regulatory requirements, or construction specifications occur. These deviations will be documented by documenting the quality problem information directly into the ATS in accordance with SBMS subject area, Quality Problem Reporting (PNNL 2005e). The assessment must describe the problem, the cause of the deviation, the impact of the problem, and the corrective action needed to remedy the immediate problem and to prevent recurrence.

Subcontractors will be required to have a system in place to identify, correct, and prevent recurrence of contractual, procedural, or regulatory requirement deviations, and to notify the PNNL point-of-contact specified when such an event occurs. These requirements will be passed on in a SOW to the subcontractors.

\subsection{Planned Deviations}

Planned deviations from procedure, documented (including justification) and approved by the Project Manager or Task Leader in advance, do not constitute a deficiency and do not require generation of an assessment item. Documentation may consist of a hard copy e-mail or memo to the Project Manager or Task Leader. This documentation must include either an approval signature if on a memo or electronic approval via a reply to the e-mail indicating such approval.

\subsection{Measuring and Test Equipment Calibration Discrepancies}

Subcontractors will be required to maintain a system for identifying calibration discrepancies and tracing data or samples that may have been affected. Subcontractors will be required, via a SOW, to notify the PNNL point-of-contact as soon as possible when such an incident occurs. PNNL will perform periodic assessments to assess the effectiveness of subcontractor procedures and processes for calibration control.

Project staff must investigate instruments or equipment found to be operating outside acceptable operating ranges (as specified in the applicable technical procedure or manufacturer's instructions) and issues must be addressed in accordance with SBMS subject area Quality Problem Reporting (PNNL 2005e). If data on an instrument's calibration report are found to be "Out of Tolerance" during the review and acceptance process, an "Out-of-Tolerance Notification will be generated using the ATS in accordance with the SBMS subject area, Assessment Management (PNNL 2005a). Then the project staff must determine if there is any impact on data. If it is determined from calibration verification that Category 1 or 2 Measuring and Test Equipment is out of tolerance, the project staff will proceed with the evaluation to determine impact on data and document the results with justification. 


\subsection{Quality Assurance Reports to Management}

Quality activities such as project improvement efforts, identification of significant deficiencies and associated corrective actions, and summary of assessment results will be reported to the Project Manager. When major quality problems are identified, they shall be reported to the Project Manager. Surveillance plans and results of the surveillances are provided to the Project Manager and Task Manager after a surveillance event.

Quality-related problems identified by project personnel must be reported to project management immediately for resolution. Any problems involving data quality, sample integrity, or test measurements will be thoroughly documented by a request for data review (RDR) and/or a Problem and Discrepancies form and communicated to the appropriate Task Leader and Project Manager for resolution.

Significant quality-related problems that may affect customer satisfaction shall be communicated to the Product Line Manager by the Project Manager.

\subsection{Records}

\subsection{Records Control}

Records that document the subcontractor activities, analytical results, verification and compliance checks, test plans, and associated results will be maintained as project records. Individual test plans and work plans may identify other records requirements. Project records will be legible, identifiable, and maintained in accordance with PNNL SBMS subject area Records Management (PNNL 2005f).

The Project Records Specialist prepares and submits a Records Inventory and Disposition Schedule (RIDS) File Index for review and approval by the records management representative and Quality Engineer. The records custodian reviews and updates the RIDS annually at a minimum, or during any major change to the program. Records retention schedules shall be based on the requirements of TPA (Ecology et al. 1989), which requires the retention of records for 10 years after termination of the TPA.

\subsection{Records Transfer to Storage}

Within 90 days of project completion or termination, records shall be transferred to storage and/or the client. The PNNL project staff member originating the transfer should complete the appropriate internal form (e.g., Records Transfer Data Input (RTDI) Form). The records management representative will sign the RTDI form as acknowledging receipt of the records and return a copy of this form to the records custodian. The RTDI form is then placed in project records.

\subsection{Procurement Control}

For this project, the majority of procurements will result in purchases of services such as drilling, sampling, and analytical. All procurements will be obtained in accordance with SBMS subject area 
Purchasing Goods and Services (PNNL 2006b). SOWs for purchasing services shall be reviewed and signed by the project Quality Engineer to assure consistency of quality assurance requirements specified to subcontractors with project quality standards in this plan.

\subsection{Groundwater Sampling}

Purchase orders (POs) shall be used to obtain sample collection and water level measurements. An electronic requisition will be prepared by project staff accompanied by a work authorization document (letter of Instruction (LOI) or SOW). The work authorization document will include requirements for sample collection, sample handling, sample labeling, custody of the samples in the field to delivery to the analytical laboratory or shipper, and water level measurements. The SOW will pass on the requirements of the EPA Requirements for Quality Assurance Project Plans (EPA/240/B-01/003, QA/R-5) and HASQARD to the subcontractor. A review must be performed by the Quality Engineer during the planning stages and preparation of the SOW/LOI.

\subsection{Groundwater Analytical Services}

Work package authorizations (WPAs), work orders (WOs), or POs, as applicable, shall be used to obtain analytical services. A letter of instruction or SOW must accompany each WO, WP, or PO. A review must be performed by the Quality Engineer during the planning stages and preparation of the SOW/LOI. The work authorization document must define the data quality and any additional project requirements associated with the service requested. The data quality requirements should include a description of the QC samples for each analysis for determining the level of possible contamination from preparation and analysis. The project requirements should include information on analysis method, calibration standards traceable to the National Institute of Standards and Technology, sample turnaround time and reporting requirements, and disposal requirements for remaining sample material and the waste from the process. The SOW will pass on the requirements of the EPA Requirements for Quality Assurance Project Plans (EPA-600/R-02/009, QA/R-5) and HASQARD to the subcontractor.

\subsection{Other Hanford Contractor Services}

Other Hanford contractor services (e.g., well drilling and construction) will be obtained using the procurement process. An electronic requisition will be generated by project staff accompanied by a work authorization document (LOI or SOW). The work authorization document will describe the requirements for the requested services. The SOW will pass on the requirements of the EPA Requirements for Quality Assurance Project Plans (EPA-600/R-02/009, QA/R-5) and HASQARD to the subcontractor. A review must be performed by the Quality Engineer during the planning stages and preparation of the SOW/LOI.

\subsection{Sediment Analytical Services}

Analytical services will be procured by using a work authorization document (LOI or SOW) accompanied by a WPA or WO. A review must be performed by the Quality Engineer during the planning stages and preparation of the SOW/LOI. The work authorization document must define the data quality and any additional project requirements associated with the service requested. The data quality requirements should include a description of the QC samples for each analysis for determining the level of possible contamination from preparation and analysis. The project requirements should include 
information on analysis method, calibration standards traceable to the National Institute of Standards and Technology, sample turnaround time and reporting requirements, and disposal requirements for remaining sample material and the waste from the process. The SOW will pass on the requirements stated in the EPA Requirements for Quality Assurance Project Plans (EPA-600/R-02/009, QA/R-5) and HASQARD to the subcontractor.

\subsection{Staff Training}

Staff performing activities affecting quality shall be issued documented training assignments including applicable project administrative and technical procedures and this plan.

1. Task Leaders and staff members will assess project-specific training needs. The assessment will include evaluating cumulative training records of the staff.

2. Task Leaders will assign reading and/or briefings of procedures as needed. If training is assessed and the need for formalized training identified, the staff member will be scheduled to attend a formal training class.

3. Task Leaders and staff will document training on a Briefing Document, an individual On-the-Job Training (OJT) or Reading Assignment Documentation form, or a Group OJT or Reading Assignment Documentation form. These forms are available internally to PNNL staff. Documentation shall be sent to the PNNL Laboratory Training Coordinator for input into the training database. The training database will contain the record copy of project staff training.

Subcontractors are responsible for special training of their staff in accordance with the respective SOW.

The project shall utilize personnel who are knowledgeable and possess adequate technical, managerial, or professional skills to perform all their assigned tasks. The project manager will identify any additional specific project-related processes that will require project staff training and will identify who will be responsible for ensuring that the project-specific training will be developed, delivered, and changes managed in accordance with the Training Design, Development, Implementation and Evaluation SBMS subject area (PNNL 2002b). The project shall maintain training documentation for projectrequired coursework or on-the-job training taken by staff that is not capable of being tracked in the Laboratory's training database in accordance with the Training and Qualification for Staff and Non-Staff SBMS subject area (PNNL 2005g).

The project manager, or his/her delegate, shall inform the immediate manager of the project staff of the staff member's need for project-required training and will ensure that the training has been completed prior to project staff conducting work that requires the training. The immediate manager of project staff, or their delegate, shall record the need for identified project-required training and ensuring training and retraining records (for both Lab-level and project -specific training) are maintained in accordance with the Training and Qualification for Staff and Non-Staff (PNNL 2005g) subject area. 
The development of software products that require complex or unfamiliar interactions with users and operators should include a comprehensive plan for training. The training plan should include the following:

a) a description of the populations to be trained, the training objectives for each population, and the content to be covered in the training

b) an estimate of the amount of resources necessary for training development, delivery, and time expenditures

c) procedures for evaluating the effectiveness of the training and for making modifications to the training.

The master project shall utilize personnel who are knowledgeable and possess adequate technical, managerial, or professional skills to perform all their assigned tasks. The master project manager has identified the following project-specific training requirements:

Project core team members will have been briefed on

- the Project Management Plan

- $\quad$ the appropriate QA plan; PNNL-SA-40114, Rev. 2. The Groundwater Performance Assessment Project Quality Assurance Plan.

The individual projects shall maintain training documentation for project-required coursework, and on-the-job training taken by staff, which is not capable of being tracked in the Laboratory's training database in accordance with the Training and Qualification for Staff and Non-Staff SBMS subject area (PNNL 2005g).

\subsection{Software Control}

Various tasks of the project require the use of databases and software, which are managed, controlled, and operated by entities that are outside PNNL. The project also requires the use of databases and software that are developed, managed, controlled, and operated by PNNL. A graded approach is used to establish software quality assurance requirements based on identified risk. Software QA at PNNL is based on DOE Order 414.1C, Quality Assurance. This order establishes specific requirements for software related to safety and nuclear facilities.

The project uses databases, custom applications, and configurable software to support various activities. These databases, custom applications, and configurable software (spreadsheets and queries) used to generate reportable results shall be documented in accordance with the SBMS subject area,

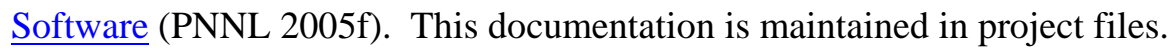

\subsection{Safety Software and Software Applications}

For the purpose of design activities covered by the projects identified in the plan, "Software" is defined as computer programs - including computer programs embedded in firmware (see Safety Software [PNNL 2006c] or Software [PNNL 2005f] SBMS subject area). Excluded is software that is an integral part of firmware or equipment, where all software maintenance is performed by the vendor and 
the software is verified as an integral part of the system (e.g., calibration with known standard materials). Any vendor will be required to follow the NQA-1-2000 (Quality Assurance Requirements for Nuclear Facility Applications) standards for software when the software that is part of firmware is identified as Safety Software. The Safety Software clause (QA-197a) will be passed down in any statements of work, at a minimum, and possibly with additional clarification, when requested by the vendor.

All Software applications used for the projects under this plan will be reviewed and identified as Safety Software or Software. The grading process for Safety Software will be recorded and copies for each application will be maintained as project records for each project that falls under this plan. Software applications that will follow this plan have the potential to be identified as Safety Software and when graded as such, will follow the Safety Software (PNNL 2006c) Level C requirements, at a minimum as identified in SBMS. The Safety Software subject area within SBMS is based on DOE Order 414.1C, which includes the NQA-1-2000 standard.

If applications are not identified as Safety Software then they will be documented as Software and the documentation will be maintained as project records for each project. Safety Software and Software applications identified for the projects in this plan will perform the work activities identified below that pertain to Custom Developed, Configurable, Acquired/Legacy, Utility Calcs and Commercial Design and Analysis Software.

All Safety Software applications are required to be identified in the Information Resource Inventory (IRI). All Safety Software will be identified as Safety System Software, Safety and Hazard Analysis Software and Design Software, or Safety Management and Administrative Controls Software. The following will additionally be identified for each software application in the IRI: Type of software, Graded Level and the scope of the software, for the intended use with the project. The owner and point of contact information will also be identified in the IRI.

\subsubsection{Minimum Documentation Requirements}

To ensure that the implementation of the software satisfies requirements, the following documentation is required as a minimum for all Safety Software applications. These document requirements must be reviewed and processed through ERICA for software code being developed as a deliverable (e.g., Hanford Soil Inventory Model (SIM) software). The rigor of the documentation will be decided based on the grading of the safety software application. Refer to the Document Content Guidance Matrix, in the Safety Software (PNNL 2005d) subject area of SBMS, for the rigor needed for the documentation requirements. The rigor requirements will be one of three categories (Detailed and Specific, Functional, or Summary level) for each document identified below:

a) Software Requirements Specifications (SRS)

b) Software Design Description (SDD)

c) Verification and Validation Plan (VVP)

d) Verification and Validation Report (VVR)

e) Configuration Management Plan (CMP)

1) A problem reporting and corrective action tracking system will be identified with CMP documentation.

2) Data management processes will also be identified, when applicable 
f) Procurement Contractual documentation, when applicable.

\subsubsection{Software Requirements Specification (SRS)}

The SRS shall clearly and precisely describe each of the essential requirements (functions, performances, design constraints, and attributes) of the software and the external interfaces. Each requirement shall be defined such that its achievement is capable of being objectively verified and validated by a prescribed method (for example: inspection, analysis, demonstration, or test).

The SRS is subject to the Software Requirements Review (SRR), identified in applicable CMPs when needed, which identifies the QA organizational element's QA activities.

\subsubsection{Software Design Description (SDD)}

The SDD shall depict how the software will be structured to satisfy the requirements in the SRS. The SDD shall describe the components and subcomponents of the software design, including data bases and internal interfaces. The SDD is a technical description of how the software will meet the requirements set forth in the SRS. Its most important function is to describe a decomposition of the whole system into components (subsystems, segments, etc.) that are complete and well-bounded. In addition, it should document the rationale for the more important design decisions in order to facilitate the understanding of the system structure.

The SDD will describe major system features such as data bases, diagnostics, external and internal interfaces, as well as the overall structure of the design. It involves descriptions of the operating environment, timing, system throughput, tables, sizing, centralized or distributed processing, extent of parallelism, client/server, reusable objects library, program design language (PDL), prototypes, modeling, simulation, etc. The SDD will also describe any input and output data that may be required.

If prototyping, modeling, or simulations are used, the QA organizational element could observe a demonstration, which is a more efficient way to review and assess written design documentation.

The SDD will be baselined after each significant review. A new version containing a more detailed design description is developed for each subsequent review.

\subsubsection{Verification and Validation Plan (VVP)}

The VVP shall identify and describe the methods (for example, inspection, analysis, demonstration, or test) to be used:

(1) To verify that:

- the requirements in the SRS have been approved by an appropriate authority,

- the requirements in the SRS are implemented in the design expressed in the SDD; and

- the design expressed in the SDD is implemented in the code.

(2) To validate that the code, when executed, complies with the requirements expressed in the SRS. 
The VVP describes the overall plan for the verification and validation of the software/modeling and will be produced and reviewed incrementally, for Safety Software applications. The tasks, methods, and criteria for verification and validation will be described in the appropriate VVPs for each application.

The VVP will be used for documentation of the testing standards and practices as they are defined in each application VVP. The VVP will explain the scope of the validation testing to ensure the baseline requirements and explain the stages of development that require customer review and the extent of the verification that will precede such a review.

The VVP will specify minimum test documentation requirements for each test performed. Additionally, a section of the VVP will identify a verification matrix where the requirements are listed with their corresponding test identified in the VVP. A matrix will be maintained during the life of the software and will be used to verify all the requirements have been met, identified, and tested.

The contents of the VVP will be evaluated at the Verification and Validation Plan Review (V\&VPR) prior to testing. A V\&VPR will be conducted when significant changes are made to the baseline. The V\&VPR will be used to identify all changes to be tested and to pass on pertinent information to the appropriate testing staff.

\subsubsection{Verification and Validation Report (VVR)}

The VVR shall describe the results of the execution of the V\&VP. The VVR summarizes the observed status of the software as a result of the execution of the VVP. The VVR should include the following information:

a) Summary of all life cycle V\&V tasks.

b) Summary of task results.

c) Summary of anomalies and resolutions.

d) Assessment of overall software quality.

e) Summary from the verification matrix. f) Recommendations such as whether the software is, or is not, ready for operational
use.

The report may be a full report or a summary (depending upon the grading of the software).

\subsubsection{User Documentation}

User documentation will be developed for applications where the code is part of the deliverable (e.g., the Hanford Soil Inventory Model (SIM)).

\subsubsection{Configuration Management Plan (CMP)}

The CMP shall document methods to be used for identifying software items, controlling and implementing changes, and recording and reporting change implementation status. The CMP should describe the tasks, methodology, and tools required to ensure that adequate Configuration Management (CM) procedures and controls are documented and are being implemented correctly. If the CMP is not a stand-alone document, and is included in the QAjP or PMP, it is not necessary that the QA organizational 
element prepare the Configuration Management Plan (CMP); however, it is essential that one exist for each project or set of applications under each project.

The CMP should describe the methods to be used for
a) Identifying all the configuration items (to determine whether or not each software item will be identified as Safety Software; if identified as Safety Software, the level will be identified as well.)
b) Controlling and implementing changes.
c) Recording and reporting change and problem reports implementation status.
d) Conducting configuration audits.
e) Identifying review and approval cycle as well as signature authority.
f) Identifying the personnel responsible for maintaining the baselines and distributing the CMP.

The CMP shall contain the information identified in the Safety Software subject area of SBMS for the appropriate level of software to which the application was graded. Most software applications for the work under these projects will be graded at Level C.

\subsection{Other Documentation}

Other specific project plans for each project under this plan may include the following:

o Project Management Plan

o Quality Assurance Plan

o Security Plan.

\subsubsection{Project Management Plan (PMP)}

The PMP can be used as the highest-level planning document governing a project or could be subordinate within a larger set of plans. The PMP should identify all technical and managerial activities associated with the project. The PMP should specify the items, to be reviewed and assessed by the QE.

\subsubsection{Security Plan}

A Security Plan is only required if any of the software tools are going to be installed on the internal PNNL sites.

\subsection{Software Use in Analysis}

This refers to the use of software of any kind by this project to conduct analyses delivered, or in support of a deliverable, to the customer. Included in this definition are data analysis tools including spreadsheets and statistical analysis software, databases, modeling, and simulation tools. Excluded are software productivity tools such as word processors and spreadsheets when no automated calculations, macros, or scripts are used. The projects under this plan shall conduct work in accord with requirements for the control of software used in analyses as defined in the Safety Software (PNNL 2006d) or Software (PNNL 2006d) SBMS subject area based on how the software being used is graded. 


\subsection{Nonconformances and Deficiencies}

For procured materials found to be in nonconformance with specifications or where the quality of an activity is found not to be in compliance, the quality problem will be documented in the ATS in accordance with the SBMS subject area, Quality Problem Reporting (PNNL 2005d). Corrective actions are documented in ATS in accordance with the SBMS subject area, Assessment Management (PNNL 2005a).

If a deficiency is found where a procedure or process is not followed or the activity is not in compliance with a procedure or process, the deficiency will be documented in the ATS in accordance with the SBMS subject area, Quality Problem Reporting (PNNL 2005d). Corrective actions will be documented using ATS in accordance with the SBMS subject area, Assessment Management (PNNL 2005a).

Subcontractors will be required to have a system to identify and disposition nonconforming items, procedure deficiencies, processes not followed, or activities not in compliance with a procedure or a process. This requirement will be specified in a SOW.

\subsection{Document Control}

\subsection{Quality Assurance Project Plan Control}

Distribution and control of this QAPjP shall be performed in accordance with SBMS subject area Publishing Scientific and Technical Information (PNNL 2002a). Modifications to this plan shall be made either by revision or by issuing an Interim Change Notice (ICN). See Figure 4 for the ICN form and instructions. This plan will be revised after four (4) ICNs or a major change in project scope or requirements. Any PNNL staff member may request a change to this QAPjP by submitting the requested change in writing to the Project Manager and Quality Engineer. All reviewers listed on the signature page and affected by the change will approve the revision. The ICN will be placed in front of the signature page and the individual pages will be replaced or the necessary correction will be lined out and correction added with initial and date. The QAPjP will be reviewed at least every two (2) years.

\subsection{Technical Procedure Control}

Technical procedures referenced by this QAPjP and used by PNNL staff will be contained in a PNNL internal procedure manual, Procedures for Ground-Water Investigations (PNL-MA-567) or other procedure manual as appropriate. Technical procedures will be distributed and controlled in accordance with SBMS subject area, Document Control (PNNL 2001). Modifications to any of the internal procedures shall be made either by revision or by issue of an ICN.

Procedures will be revised after two major ICNs or if the procedure format has changed. Any PNNL staff member may request a change to procedures at any time by submitting the requested change in writing to the author. The author, technical reviewer, groundwater project Task Manager, and project Quality Engineer will review and approve the ICN. The ICN will be placed in front of the signature page and the individual pages will be replaced or the necessary correction will be lined out and correction 
added with initial and date. Contact the Project Quality Engineer for the electronic copy of the ICN. New or revised technical procedures, whether they will be included in the internal procedures manual or not, must be developed in accordance with SBMS subject area, Procedures, Permits, and Other Work Instructions (PNNL 2004). The procedure owner is required to review the procedure at least every three (3) years.

\subsection{Administrative Procedure/Instruction Preparation and Control}

Administrative procedures/instructions used by PNNL staff will be developed, approved, and controlled to ensure consistent application by those staff performing the defined task(s). These procedures/instructions will be developed, approved, and controlled in a manner that has been approved by appropriate project management and the Quality Engineer.

\subsection{Test Plans and Other Work Documents}

Test Plans and other work instructions used by PNNL staff will be developed, approved, and controlled to ensure consistent application by those staff performing the defined task(s). These procedures/instructions will be developed, approved, and controlled in a manner that has been approved by appropriate project management and the Quality Engineer. Distribution and control of test plans and other plans shall be performed in accordance with SBMS subject area Publishing Scientific and Technical Information (PNNL 2002a). 


\section{INSTRUCTIONS FOR ICN FORM}

HEADER:

The ICN number is identified as ICN No.-

For a published groundwater monitoring plan, each page of the ICN shall have a header on the right upper corner that includes the report number, the date and the pagination. The number of the ICN must be placed after the PNNL number. The second line of the header should show the date and pagination. The cover sheet needs to identify how many pages are in the ICN packet.

Example header: $\quad$ PNNL-Xxxxx-ICN-x

Month, day, year; Page $\mathrm{x}$ of $\mathrm{xx}$

\section{SECTION A.}

Self-explanatory.

\section{SECTION B.}

Include all actions that the document holder must take to update the procedure or instruction. Possible actions include: replacing pages of the document with pages that are distributed with the ICN and marking up the document (in ink) to reflect the changes identified on the ICN or attaching the ICN cover sheet to the front of the document.

For a "Published" groundwater monitoring plan, include the following statement: "Attach this ICN to the front of the document, just before the title page."

\section{SECTION C.}

Identify, by title, all personnel whose job functions will be affected by the change and include a brief description of the effect. If there is no effect on personnel (e.g., the change was made to clarify the intent of the procedure or to correct a typographical error) this block should be marked "N/A."

\section{SECTION D.}

State the reason for the change followed by a description of the change (including the affected paragraph, information that is deleted, and the actual wording of any replacement test) for each change included on the ICN.

\section{SECTION E.}

The Cognizant Manager shall document the reason for not obtaining original reviewers' approval and/or any other decisions that must be documented. Additionally, list the individuals who will receive the document (distribution list).

\section{SECTION F.}

Identify type of change and document required approvals.

Figure 4. Interim Change Notice 


\section{INTERIM CHANGE NOTICE}

(ICN)

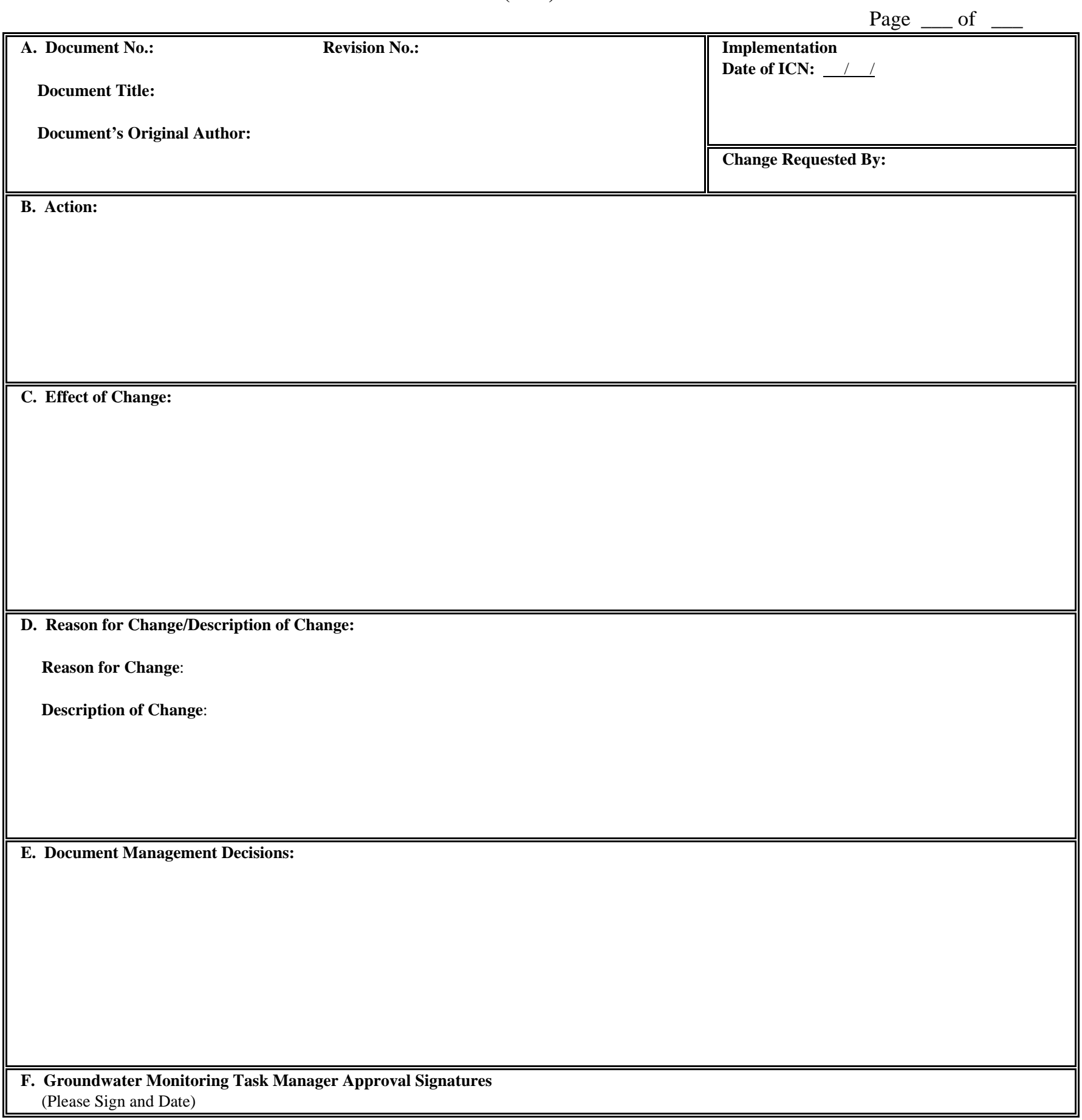

Project Quality Engineer Approval:

Date:

Author Approval:

Date:

Other Approvals:

Date:

Figure 4. (contd) 


\subsection{References}

10 CFR 830. "Energy/Nuclear Safety Management, Subpart A--Quality Assurance Requirements.” U.S. Code of Federal Regulations.

40 CFR 136. “Guidelines Establishing Test Procedures for the Analysis of Pollutants, Appendix B-Definition and Procedure for the Determination of the Method Detection Limit-Revision 1.11.” U.S. Code of Federal Regulations.

40 CFR 264. "Standards for Owners and Operators of Hazardous Waste Treatment, Storage, and Disposal Facilities.” U.S. Code of Federal Regulations.

40 CFR 265. "Interim Status Standards for Owners and Operators of Hazardous Waste Treatment, Storage, and Disposal Facilities.” U.S. Code of Federal Regulations.

Atomic Energy Act. 1954, as amended, Ch. 1073, 68 Stat. 919, 42 USC 2011 et seq.

CAWSRP - Conducting Analytical Work in Support of Regulatory Programs. 2006. Pacific Northwest National Laboratory. Available online at http://etd.pnl.gov/docs/conducting-work/index.stm

CERCLA - Comprehensive Environmental Response, Compensation, and Liability Act. 1980. Public Law 96-150, as amended, 94 Stat. 2767, 42 USC 9601 et seq.

DOE Order 414.1C. 2005. Quality Assurance. U.S. Department of Energy, Washington, D.C.

DOE Order 435.1. 2001. Radioactive Waste Management. U.S. Department of Energy, Washington, D.C.

DOE Order 450.1. 2003, as amended. Environmental Management System. U.S. Department of Energy, Washington, D.C.

DOE Order 5400.5. 1993, as amended. Radiation Protection of the Public and the Environment. U.S. Department of Energy, Washington, D.C.

DOE/RL-96-68. 1998. Hanford Analytical Services Quality Assurance Requirements Documents. HASQARD, Volumes 1, 2, 3, and 4. U.S. Department of Energy, Richland Operations Office, Richland, Washington.

Ecology - Washington State Department of Ecology, U.S. Environmental Protection Agency, and U.S. Department of Energy. 1989, as amended. Hanford Federal Facility Agreement and Consent Order. Document No. 89-10 (The Tri-Party Agreement), Olympia, Washington.

Ecology - Washington State Department of Ecology. 1994, as amended. Hanford Facility Resource Conservation and Recovery Act Permit, Dangerous Waste Portion Revision 8 for the Treatment, Storage, and Disposal of Dangerous Waste, Permit Number: WA7890008967. Olympia, Washington.

EMSL-LV-0539-17. 1979. Radiochemical Analytical Procedures for Analysis of Environmental Samples. U.S. Environmental Protection Agency, Las Vegas, Nevada. 
EPA/240/B-01/003 (QA/R-5). 2001. EPA Requirements for Quality Assurance Project Plans. U.S. Environmental Protection Agency, Washington, D.C.

EPA/240/B-06/001 (QA/G-4). 2006. Guidance on Systematic Planning Using the Data Quality Objectives Process. U.S. Environmental Protection Agency, Washington, D.C.

EPA-600/4-79/019. 1979. Handbook for Analytical Quality Control in Water and Wastewater Laboratories. U.S. Environmental Protection Agency, Cincinnati, Ohio.

EPA-600/4-79-020. 1983. Methods for Chemical Analysis of Water and Wastes. U.S. Environmental Protection Agency, Washington, D.C.

EPA-600/4-80-032. 1980. Prescribed Procedures for Measurement of Radioactivity in Drinking Water. U.S. Environmental Protection Agency, Cincinnati, Ohio.

EPA-600/4-88-039. 1988. Methods for the Determination of Organic Compounds in Drinking Water. U.S. Environmental Protection Agency, Washington, D.C.

EPA/600/R-96/055. 2000. Guidance for the Data Quality Objectives Process (QA/G-4), U.S. Environmental Protection Agency, Washington, D.C.

EPA-R4-73-014. 1973. Procedures for Radiochemical Analysis of Nuclear Reactor Aqueous Solutions. U.S. Environmental Protection Agency, Cincinnati, Ohio.

EPA/SW-846. 1986, as amended. Test Methods for Evaluating Solid Waste: Physical/Chemical Methods, SW-846, Third Edition. Office of Solid Waste and Emergency Response, U.S. Environmental Protection Agency, Washington, D.C. Available online at http://www.epa.gov/epaoswer/hazwaste/test/main.htm

NQA-1-2000. 2001. Quality Assurance Requirements for Nuclear Facility Applications, The American Society of Mechanical Engineers, New York, New York.

PAAA-Price-Anderson Amendments Act. Energy Policy Act of 2005. Title VI-Nuclear Matters, Subtitle A-Price-Anderson Act Amendments, Section 601 et.seq. Public Law 109-58, as amended. 42 USC 15801 et seq.

PNL-MA-567. 1993, as amended. Procedures for Ground-Water Investigations. Pacific Northwest National Laboratory, Richland, Washington.

PNL-MA-580. 2004. Surface Environmental Surveillance Procedures Manual, Revision 4. Pacific Northwest National Laboratory, Richland, Washington.

PNNL. 2001. Document Control. Standards-Based Management System, Pacific Northwest National Laboratory, Richland, Washington. Available online at http://sbms.pnl.gov/standard/2m/2m00t010.htm

PNNL. 2002a. Publishing Scientific and Technical Information. Standards-Based Management System, Pacific Northwest National Laboratory, Richland, Washington. Available online at http://sbms.pnl.gov/standard/80/8000t010.htm 
PNNL. 2002b. Training Design, Development, Implementation and Evaluation. Standards-Based Management System, Pacific Northwest National Laboratory, Richland, Washington. Available online at http://sbms.pnl.gov/standard/1f/1f00t010.htm

PNNL. 2004. Procedures, Permits, and Other Work Instructions. Standards-Based Management System, Pacific Northwest National Laboratory, Richland, Washington. Available online at http://sbms.pnl.gov/standard/74/7400t010.htm

PNNL. 2005a. Assessment Management. Standards-Based Management System, Pacific Northwest National Laboratory, Richland, Washington. Available online at http://sbms.pnl.gov/standard/4i/4i00t010.htm

PNNL. 2005b. Calibration. Standards-Based Management System, Pacific Northwest National Laboratory, Richland, Washington. Available online at http://sbms.pnl.gov/standard/79/7900t010.htm

PNNL. 2005c. Planning Assessment, and Analysis. Standards-Based Management System, Pacific Northwest National Laboratory, Richland, Washington. Available online at http://sbms.pnl.gov/standard/18/1800t010.htm

PNNL. 2005d. Quality Problems Reporting. Standards-Based Management System, Pacific Northwest National Laboratory, Richland, Washington. Available online at http://sbms.pnl.gov/standard/78/7800t010.htm

PNNL. 2005e. Records Management. Standards-Based Management System, Pacific Northwest National Laboratory, Richland, Washington. Available online at http://sbms.pnl.gov/standard/1a/1a00t010.htm

PNNL. 2005f. Software. Standards-Based Management System, Pacific Northwest National Laboratory, Richland, Washington. Available online at http://sbms.pnl.gov/standard/94/9400t010.htm

PNNL. 2005g. Training and Qualification for Staff and Non-Staff. Standards-Based Management System, Pacific Northwest National Laboratory, Richland, Washington. Available online at http://sbms.pnl.gov/standard/1e/1e00t010.htm

PNNL. 2006a. Price-Anderson Amendments Act. Standards-Based Management System, Pacific Northwest National Laboratory, Richland, Washington. Available online at http://sbms.pnl.gov/standard/11/1100t010.htm

PNNL. 2006b. Purchasing Goods and Services. Standards-Based Management System, Pacific Northwest National Laboratory, Richland, Washington. Available online at http://sbms.pnl.gov/standard/3i/3i00t010.htm

PNNL. 2006c. Sample Handling, Archival, and disposal. Standards-Based Management System, Pacific Northwest National Laboratory, Richland, Washington. Available online at http://sbms.pnl.gov/standard/6e/6e00t010.htm

PNNL. 2006d. Safety Software. Standards-Based Management System, Pacific Northwest National Laboratory, Richland, Washington. Available online at http://sbms.pnl.gov/standard/6e/6e00t010.htm 
PNNL-15014. Groundwater Performance Assessment Project Quality Assurance Plan, current revision. Pacific Northwest National Laboratory, Richland, Washington.

QAP ESL. Environmental Sciences Laboratory QA Plan, current revision. Pacific Northwest National Laboratory, Richland, Washington.

RCRA - Resource Conservation and Recovery Act. 1976. Public Law 94-580, as amended, 90 Stat. 2795, 42 USC 6901 et seq.

U.S. Geological Survey. 1977. National Handbook of Recommended Methods for Water Data Acquisition. Office of Water Data Coordination. Reston, Virginia.

WAC 173-160. "Minimum Standards for Construction and Maintenance of Wells.” Washington Administrative Code, Olympia, Washington. 


\section{Appendix A}

The Columbia River Protection Supplemental Technologies Project Quality Control Plan 



\title{
Appendix A
}

\section{The Columbia River Protection Supplemental Technologies Project Quality Control Plan}

\begin{abstract}
A.1 Introduction
The quality control (QC) practices and analytical performance requirements described in the Groundwater Performance Assessment Project Quality Assurance Plan Appendix (QC Plan) and/or the Environmental Sciences Laboratory QA Plan are applied to most groundwater samples collected for the Technology Project. If the specific analyses, performance requirements, and/or QC requirements differ from those provided in the Groundwater Performance Assessment Project QA Plan, they will be documented in the specific test plans.
\end{abstract}

\section{A.2 Requirements for Sediment and other Non-Aqueous Media Samples}

The Technology Project will have sediment samples, insect samples, vegetation samples, and other media samples analyzed. The wide variety of sample media and diverse nature of this work precludes specification of many of the requirements in this QA Plan. Therefore, the types, quantities, and acceptance criteria for field and/or laboratory QC samples are specified in test plans and/or the laboratory statement of work. 
A. 2 


\section{Appendix B}

Additional Analyses and Measurements to be Employed for the Treatability Studies 



\section{Appendix B}

\section{Additional Analyses and Measurements to be Employed for the Treatability Studies}

\begin{tabular}{|c|c|c|c|}
\hline Method & Analysis & Document Number & Procedure Title \\
\hline $\begin{array}{l}\text { Conduct of Routine } \\
\text { Laboratory Operations }\end{array}$ & General & RPL-OP-001 & $\begin{array}{l}\text { Routine Research Operations } \\
\text { Section } 31 \text { tab } 3 \text { of } \\
\text { RPL Laboratory Handbook }\end{array}$ \\
\hline $\begin{array}{l}\text { Inductively Coupled } \\
\text { Plasma-Optical Emission } \\
\text { Spectroscopy (ICP-OES) }\end{array}$ & $\begin{array}{l}\mathrm{Ca}, \mathrm{Fe}, \mathrm{K}, \mathrm{Mg}, \mathrm{Mn}, \mathrm{Na}, \\
\mathrm{P}, \mathrm{S}, \mathrm{Si}\end{array}$ & PNNL-AGG-ICP-AES* & $\begin{array}{l}\text { Inductively Couple Plasma - } \\
\text { Optical Emission Spectrometry } \\
\text { (ICP-OES) Analysis }\end{array}$ \\
\hline $\begin{array}{l}\text { Inductively Coupled } \\
\text { Plasma-Mass Spectroscopy } \\
\text { (ICP-MS) }\end{array}$ & Re, Tc & PNNL-AGG-415 & $\begin{array}{l}\text { Inductively Coupled Plasma } \\
\text { Mass Spectrometric (ICP-MS) } \\
\text { Analysis }\end{array}$ \\
\hline Ion Chromatography (IC) & $\mathrm{Cl}, \mathrm{F}$ & AGG-IC-001 & $\begin{array}{l}\text { Determinations by Ion } \\
\text { Chromatography (IC) }\end{array}$ \\
\hline $\begin{array}{l}\text { Solid-State pH Electrode } \\
\text { and Meter }\end{array}$ & $\mathrm{pH}$ & AGG-PH-001 & $\mathrm{pH}$ Measurement \\
\hline X-Ray Diffraction (XRD) & Mineralogy & RPL-XRD-PIP & $\begin{array}{l}\text { Operation of Scintag Pad-V } \\
\text { X-Ray Diffractor (RGD \#62) }\end{array}$ \\
\hline $\begin{array}{l}\text { Scanning Electron } \\
\text { Microscopy/Energy- } \\
\text { Dispersive X-ray } \\
\text { Spectrometry (SEM/EDS) }\end{array}$ & $\begin{array}{l}\text { Particle morphology, } \\
\text { size, and qualitative } \\
\text { elemental analysis }\end{array}$ & PNL-SP-3 & $\begin{array}{l}\text { Scanning Electron } \\
\text { Microscopy/Energy Dispersive } \\
\text { Spectrometry }\end{array}$ \\
\hline Particle Size Distribution & & PNL-MA-567, SA-3 & $\begin{array}{l}\text { Particle-size analysis (pipette or } \\
\text { hydrometer method); Wet sieve } \\
\text { analysis will be used to remove } \\
\text { sand-size particle }\end{array}$ \\
\hline Hydraulic Conductivity & & PNL-MA-567, SA-5 & $\begin{array}{l}\text { Falling head hydraulic } \\
\text { conductivity }\end{array}$ \\
\hline Water Retention & & UFA-SK-01 & $\begin{array}{l}\text { Determination of water retention } \\
\text { as a function of water content } \\
\text { using open-flow centrifugation } \\
\text { techniques }\end{array}$ \\
\hline Water Content & & PNL-MA-567, SA-7 & Water content \\
\hline Bulk Density & & PNL-MA-567, SA-8 & Clod density/bulk density \\
\hline Particle Density & & PNL-MA-567, SA-9 & $\begin{array}{l}\text { Determining particle density; } \\
\text { necessary for constant head } \\
\text { hydraulic conductivity }\end{array}$ \\
\hline Column Packing & & $\begin{array}{l}\text { WHC-IP-0635, GEL-3 } \\
\text { Rev.3 }\end{array}$ & $\begin{array}{l}\text { Moisture relationships of soils; } \\
\text { necessary for constant head } \\
\text { hydraulic conductivity }\end{array}$ \\
\hline $\mathrm{pH} / \mathrm{EC}$ & & PNL-G-5-pH/EC & $\begin{array}{l}\text { Measuring } \mathrm{pH} / \mathrm{EC} \text { of low-level } \\
\text { radioactive solutions }\end{array}$ \\
\hline Saturated column & & AGG-SAT-COL-001 & Conducting saturated column \\
\hline
\end{tabular}




\begin{tabular}{|l|l|l|l|}
\hline \multicolumn{1}{|c|}{ Method } & \multicolumn{1}{|c|}{ Analysis } & \multicolumn{1}{c|}{ Document Number } & \multicolumn{1}{c|}{ Procedure Title } \\
\hline experiments & & & experiments \\
\hline Batch experiments & & AGG-BSE-001 & Batch sorption experiments \\
\hline Surface Area & AGG-SA-001 & Measuring Surface area \\
\hline * $\begin{array}{l}\text { The document number states ICP-AES, but the instrument in use is an ICP-OES. ICP-AES and ICP-OES are equivalent } \\
\text { and refer to the same analytical technique. }\end{array}$
\end{tabular}




\section{Appendix C}

\section{Experimental and Modeling Procedures for Subsurface Science}

Representative Sites Task 



\section{Appendix C}

\section{Experimental and Modeling Procedures for Subsurface Science Representative Sites Task}

\begin{tabular}{|c|c|c|}
\hline $\begin{array}{l}\text { Method// } \\
\text { Instrument }\end{array}$ & Analyses/Calculations & Procedures \\
\hline ICP/AES & $\begin{array}{l}\text { Ca, K, Mg, P, Sr, Na, Si, Cu, Fe, Mn, S, and Ti in } \\
\text { water in ppb or moles/L }\end{array}$ & *PNNL-AGG-ICP-AES \\
\hline ICP/MS & $\mathrm{Cu}, \mathrm{Fe}$ in water in ppb or moles/L & PNL-SAND-3.1 (needs updated) \\
\hline $\begin{array}{l}\text { Ion } \\
\text { Chromatograp } \\
\text { hy }\end{array}$ & $\begin{array}{l}\mathrm{F}, \mathrm{Cl}, \mathrm{NO}_{2}, \mathrm{NO}_{3}, \mathrm{CO}_{3}, \mathrm{SO}_{4}, \mathrm{PO}_{4}, \mathrm{PO}_{4} \text { in water in ppm } \\
\text { or moles/L }\end{array}$ & *PNNL-AGG-IC-001 \\
\hline KPA & U in water in ppb or moles/L & Liu et al. 2004 \\
\hline $\begin{array}{l}\text { Spectrophotom } \\
\text { eter }\end{array}$ & $\mathrm{Fe}(\mathrm{II})$ and total Fe in ppb & Kukkadapu et al. 2004 \\
\hline LSC & Sr90, Tc99, I129, in dpm/mL & $\begin{array}{l}\text { *PNNL-AGG-RRL-002; Procedures } \\
\text { vary slightly for different radioisotopes; } \\
\text { McKinley et al.(2006) for Sr90 (PNNL- } \\
\text { AGG procedures are from PNNL’s } \\
\text { Applied Geochemistry Group) }\end{array}$ \\
\hline Potentiometric & pH, Bromide & *PNNL-AGG-pH-001 \\
\hline TIC/TOC & Inorganic C, organic C, total C & *PNNL-AGG-TOC-001 \\
\hline $\begin{array}{l}\text { X-ray } \\
\text { Fluorescence }\end{array}$ & $\begin{array}{l}\text { Total analyses of sediments including Al, Si, K, Ca, } \\
\mathrm{Mg}, \mathrm{Sr}, \mathrm{Ti}, \mathrm{Fe}, \mathrm{Mn}, \mathrm{Cu}, \mathrm{Ni}, \mathrm{Cr}, \mathrm{Cs}, \mathrm{U} \text {, and others. }\end{array}$ & *PNNL-AGG-OP-RGD74-001 \\
\hline $\begin{array}{l}\text { Conventional } \\
\text { Powder X-ray } \\
\text { Diffraction }\end{array}$ & Mineral identity (\% distribution) & Qafoku et al. 2005 \\
\hline $\begin{array}{l}\text { Digital } \\
\text { Autoradiograp } \\
\text { hy }\end{array}$ & $\begin{array}{l}\text { Identify locations of radioactivity in sediment thin } \\
\text { section and mixtures of sand and silt-sized particles. }\end{array}$ & Zeissler et al 2001; McKinley et al. 2001 \\
\hline $\begin{array}{l}\text { Scanning } \\
\text { Electron } \\
\text { Microscopy } \\
\text { with WDS } \\
\end{array}$ & $\begin{array}{l}\text { High resolution imaging of particle morphology and } \\
\text { atomic mass generally in sediment thin section; semi } \\
\text { quantitative imaging of chemical distribution. }\end{array}$ & McKinley et al, 2005 \\
\hline $\begin{array}{l}\text { Transmission } \\
\text { Electron } \\
\text { Microscopy } \\
\text { with Selected } \\
\text { Area } \\
\text { Diffraction } \\
\text { (SAED) }\end{array}$ & $\begin{array}{l}\text { Very high resolution of single mineral grains in cross } \\
\text { section; local morphology, structure and atomic } \\
\text { arrangement. }\end{array}$ & $\begin{array}{l}\text { Zachara et al. 2006. Selected area } \\
\text { diffraction patterns are interpreted using } \\
\text { the JADE software (see below) using x- } \\
\text { ray powder diffraction data (PDF) } \\
\text { retrieved from a standards library } \\
\text { (ICDD, 2003) }\end{array}$ \\
\hline $\begin{array}{l}\text { Electron } \\
\text { microprobe }\end{array}$ & $\begin{array}{l}\text { Quantitative, intermediate sensitivity chemical } \\
\text { mapping in thin sections. Chemical transects across } \\
\text { grain/particle boundaries. }\end{array}$ & Wang et al. 2005b; Catalano et al. 2006 \\
\hline $\begin{array}{l}\text { X-ray } \\
\text { fluorescence } \\
\text { microprobe }\end{array}$ & $\begin{array}{l}\text { High sensitivity, semi quantitative mapping of } \\
\text { element distributions in sediment thin sections at } \\
\text { scales of } 10 \mu \mathrm{m} \text {. }\end{array}$ & Liu et al. 2004; Fredrickson et al. 2004 \\
\hline $\begin{array}{l}\text { X-ray } \\
\text { absorption } \\
\text { spectroscopy }\end{array}$ & $\begin{array}{l}\text { Determination of element coordination structure, } \\
\text { nearest neighbors, and bond distances in contaminated } \\
\text { sediment. }\end{array}$ & $\begin{array}{l}\text { Catalano et al. 2004; Catalano et al. } 2006 \\
\text { Basic experimental synchrotron } \\
\text { measurements are modeled with FEFF, } \\
\text { FEFFIT, and IFEFFIT (see below) to }\end{array}$ \\
\hline
\end{tabular}




\begin{tabular}{|c|c|c|}
\hline $\begin{array}{l}\text { Method/ } \\
\text { Instrument }\end{array}$ & Analyses/Calculations & Procedures \\
\hline & & extract molecular information. \\
\hline $\begin{array}{l}\text { Synchrotron } \\
\text { diffraction }\end{array}$ & $\begin{array}{l}\text { Identification of mineral structures in sediment thin } \\
\text { sections. }\end{array}$ & $\begin{array}{l}\text { Catalano et al. 2004. Mineral structures } \\
\text { are derived by application of the FIT2D } \\
\text { software (see below). }\end{array}$ \\
\hline $\begin{array}{l}\text { Cryogenic } \\
\text { laser induced } \\
\text { fluorescence } \\
\text { spectroscopy } \\
\text { (CLIFS) }\end{array}$ & $\begin{array}{l}\text { Vibronic spectra of U(VI) in water and solids to } \\
\text { establish molecular and mineralogic environment. }\end{array}$ & $\begin{array}{l}\text { Wang et al. } 2004 \text { (for aqueous solu- } \\
\text { tions); Wang et al. 2005a (for solids). } \\
\text { Data analysis with IGOR and Globals } \\
\text { programs (see below). }\end{array}$ \\
\hline $\begin{array}{l}\text { Batch kinetic } \\
\text { desorption } \\
\text { experiments }\end{array}$ & $\begin{array}{l}\text { Sediments are bathed in electrolyte of known } \\
\text { composition and the time-variant release of } \\
\text { contaminants and other solid associated ions are } \\
\text { monitored by aqueous phase analyses. }\end{array}$ & $\begin{array}{l}\text { Procedures vary as per element and its } \\
\text { concentration. Examples include Liu et } \\
\text { al. } 2003 \text { (Cs137); Liu et al. } 2004 \text { (U); } \\
\text { McKinley et al. 2005 (Sr90). Kinetic } \\
\text { rate laws and rate constants are } \\
\text { calculated from the data using micro- } \\
\text { scopic, diffusion-based transport models } \\
\text { (See below). Steady state values can be } \\
\text { used to establish thermodynamic } \\
\text { parameters, such as the solubility } \\
\text { product of a precipitated contaminant } \\
\text { phase (e.g. Ilton et al. 2006). }\end{array}$ \\
\hline $\begin{array}{l}\text { Batch } \\
\text { adsorption } \\
\text { experiments }\end{array}$ & $\begin{array}{l}\text { Sediments are bathed in electrolyte of known } \\
\text { composition that has been spiked with a contaminant } \\
\text { of interest. The adsorption of the contaminant is } \\
\text { monitored as a function of } \mathrm{pH} \text {, ionic strength, or ion } \\
\text { composition. }\end{array}$ & $\begin{array}{l}\text { Example procedures are equilibrium - } \\
\text { Turner et al. } 1996 \text { (U) and Zachara et al. } \\
2002 \text { (Cs); kinetic - Liu et al. } 2003 \text { (Cs), } \\
\text { Liu et al. } 2004 \text { (U), and McKinley et al. } \\
2006 \text { (Sr). Experimental results are } \\
\text { fitted with various geochemical models } \\
\text { (MINTEQ; Geochemists Workbench; } \\
\text { GMIN; or FITEQL see below) to } \\
\text { identify suites of adsorption reactions } \\
\text { (ion exchange or surface complexation). }\end{array}$ \\
\hline $\begin{array}{l}\text { Column } \\
\text { experiments }\end{array}$ & $\begin{array}{l}\text { Sediment ( }<2 \mathrm{~mm} \text { or }<4 \mathrm{~mm} \text { ) is packed into a } \\
\text { cylindrical plastic, glass, or stainless steel column. } \\
\text { Electrolyte with or without a contaminant tracer is } \\
\text { applied to the column to study the release (from } \\
\text { contaminated sediment) or sorption/retardation (for } \\
\text { uncontaminated sediments) of key contaminants of } \\
\text { concern. }\end{array}$ & $\begin{array}{l}\text { Qafoku et al. 2005. The data is in the } \\
\text { form of chemical concentration as a } \\
\text { function of leaching volume of fluid and } \\
\text { must be modeled with commercial and } \\
\text { research codes to yield useable infor- } \\
\text { mation. CXTFIT is used to fit physical } \\
\text { transport parameters such as dispersivity, } \\
\text { while other models are linked with a } \\
\text { solver of the advective-dispersion } \\
\text { equation to describe 1-dimensional } \\
\text { reactive transport. The reactive transport } \\
\text { models include a commercial one (the } \\
\text { Geochemists Workbench) and others } \\
\text { assembled by the research team } \\
\text { including the Distributed Rate Model } \\
\text { (DRM) and the Dual Continuum Model } \\
\text { (DCM). These are described below. }\end{array}$ \\
\hline $\begin{array}{l}\text { MINTEQA2 } \\
\text { Version } 4\end{array}$ & $\begin{array}{l}\text { Commercial software used to calculate aqueous } \\
\text { speciation, precipitation/dissolution, and } \\
\text { adsorption/desorption equilibria for low- to } \\
\text { intermediate-strength solutions. }\end{array}$ & $\begin{array}{l}\text { Code published by Allison et al. } 1991 \\
\text { and } 1998 \text { linked to a thermodynamic } \\
\text { data base of our own synthesis (see } \\
\text { below). }\end{array}$ \\
\hline
\end{tabular}




\begin{tabular}{|c|c|c|}
\hline $\begin{array}{l}\text { Method/ } \\
\text { Instrument }\end{array}$ & Analyses/Calculations & Procedures \\
\hline $\begin{array}{l}\text { Geochemists } \\
\text { Workbench }\end{array}$ & $\begin{array}{l}\text { Commercial software to calculate geochemical } \\
\text { equilibria, reaction network modeling, and reactive } \\
\text { transport. }\end{array}$ & $\begin{array}{l}\text { Geochemists Workbench Release } 6 . \\
\text { from Craig Bethke, Hydrogeology } \\
\text { Program, University of Illinois }\end{array}$ \\
\hline CXTFIT & Commercial software for fitting column effluent data. & Toride et al. 1999 \\
\hline $\begin{array}{l}\text { FITEQL (V } \\
4.0)\end{array}$ & $\begin{array}{l}\text { Commercial software used to calculate equilibrium } \\
\text { constants and their statistics for aqueous, surface, and } \\
\text { precipitated phases from batch experimental data. }\end{array}$ & Herbelin and Westall 1999 \\
\hline GMIN & $\begin{array}{l}\text { An equilibrium geochemical model used to calculate } \\
\text { aqueous speciation, precipitation/ dissolution, and } \\
\text { adsorption desorption equilibria for high ionic } \\
\text { strength solutions. Maintained by PNNL. }\end{array}$ & Felmy 1995 \\
\hline $\begin{array}{l}\text { Spectral Fitting } \\
\text { Software }\end{array}$ & $\begin{array}{l}\text { Commercial software used to fit fluorescence } \\
\text { emission spectra on U(VI) derived from CLIFS } \\
\text { analyses. The fitting allows determination of the } \\
\text { precise spectral wavelengths and deconvolutes } \\
\text { spectral signatures resulting from multiple } \\
\text { fundamental species. }\end{array}$ & Beechem et al. 1991 \\
\hline $\begin{array}{l}\text { Phase } \\
\text { Identification } \\
\text { for Powder } \\
\text { Diffraction } \\
\text { (JADE+, V 5) }\end{array}$ & $\begin{array}{l}\text { Commercial software used to manipulate powder } \\
\text { diffraction files are for comparison with reference } \\
\text { spectra in for mineral identification. }\end{array}$ & $\begin{array}{l}\text { Materials Data Inc. Livermore, CA; } \\
\text { ICDD } 2003\end{array}$ \\
\hline $\begin{array}{l}\text { Reactive } \\
\text { Transport } \\
\text { Modeling }\end{array}$ & $\begin{array}{l}\text { The Dual Continuum Model (DCM) is used to model } \\
\text { the reactive transport of contaminants in one-dimen- } \\
\text { sional laboratory columns and in multidimensional } \\
\text { field simulations. Model is a reaction-based simulator } \\
\text { and requires significant parameterization using batch } \\
\text { and column data and physical measurements of } \\
\text { sediment characteristics. Maintained by LANL. }\end{array}$ & Lichtner et al. 2000; Lichtner et al. 2001 \\
\hline $\begin{array}{l}\text { Empirical } \\
\text { Kinetic } \\
\text { Modeling }\end{array}$ & $\begin{array}{l}\text { The distributed rate model (DRM) is used to } \\
\text { empirically describe complex kinetic } \\
\text { desorption/dissolution phenomena in sediment that is } \\
\text { controlled by chemical kinetics or diffuse mass } \\
\text { transport. The basic model describes kinetic } \\
\text { phenomena using a statistical distribution of first } \\
\text { order rate constants. Maintained at PNNL. }\end{array}$ & Culver et al. 1997 \\
\hline $\begin{array}{l}\text { Surface } \\
\text { Complexation } \\
\text { Model }\end{array}$ & $\begin{array}{l}\text { The surface complexation model (SCM) is used to } \\
\text { describe the surface chemical reactions of U(VI) that } \\
\text { are responsible for its adsorption to vadose zone and } \\
\text { aquifer sediments. Maintained by USGS. }\end{array}$ & Davis et al. 2004 \\
\hline $\begin{array}{l}\text { Thermodynami } \\
\text { c Data Base }\end{array}$ & $\begin{array}{l}\text { A large thermodynamic database that is constantly } \\
\text { updated based on literature advances. The database } \\
\text { describes stability constants for aqueous complexes } \\
\text { and solubility products for precipitated phases } \\
\text { relevant to S\&T research and issues. This database is } \\
\text { used in almost every S\&T geochemical study. There } \\
\text { are hundreds of entries in the database for a variety of } \\
\text { contaminants that are used in MINTEQA@; } \\
\text { Geochemists Workbench, and all of the reactive } \\
\text { transport codes. Maintained at PNNL. }\end{array}$ & $\begin{array}{l}\text { The database relies on the following and } \\
\text { many other sources: Grenthe et al. } 1992 \\
\text { (U); Guillaumount et al. } 2003 \text { (U); Rard } \\
1999 \text { (Tc) }\end{array}$ \\
\hline
\end{tabular}




\section{Appendix C References}

Allison, J. D., D. S. Brown, and K. J. Novo-Gradac. 1991. MINTEQA2/PRODEFA2, A Geochemical Assessment Model for Environmental Systems: Version 3.0 User's Manual; U.S. Environmental Protection Agency, Washington, DC.

Allison, J. D., D. S. Brown, and K. J. Novo-Gradac. 1998. MINTEQA2/PRODEFA2, A Geochemical Assessment Model for Environmental Systems: User Manual Supplement for Version 4.0; U.S. Environmental Protection Agency, Washington, DC.

Beechem, J. M., E. Gratton, and W. W. Mantulin. 1991. Globals Unlimited, UIUC Publication. Catalano, J. G., J. P. McKinley, J. M. Zachara, S. C. Smith, and G. E. Brown, Jr. 2006. Changes in uranium speciation through a depth sequence of contaminated Hanford sediments. Environmental Science \& Technology (Submitted).

Catalano, J. G., S. M. Heald, J. M. Zachara, and G. E. Brown, Jr. 2004. Spectroscopic and diffraction study of uranium speciation in contaminated vadose zone sediments from the Hanford Site, Washington State. Environ. Sci. Technol., 38:2822-2828.

Culver, T. B., S. P. Hallisey, D. Sahoo, J. J. Deitsch, and J. A. Smith. 1997. Modeling the desorption of organic contaminants from long-term contaminated soil using distributed mass transfer rates. Environ. Sci. Technol., 31:1581-1588.

Davis, J. A., D. E. Meece, M. Kohler, and G. P. Curtis. 2004. Approaches to surface complexation modeling of uranium(VI) adsorption on aquifer sediments. Geochim. Cosmochim. Acta, 68:3621-3641.

Felmy, A. R. 1995. GMIN. A computerized chemical equilibrium program using a constrained minimization of the Gibbs free energy: Summary report. In Chemical Equilibrium and Reaction Models (eds. R. H. Loeppert, A. P. Schwab, and S. Goldberg) pp. 377-407, Soil Science Society of America.

Fredrickson, J. K., J. M. Zachara, D. W. Kennedy, R. K. Kukkadapu, J. P. McKinley, S. M. Heald, C. Liu, and A. E. Plymale. 2004. Reduction of TcO4- by sediment-associated biogenic Fe(II). Geochim. Cosmochim. Acta, 68(15):3171-3187.

Grenthe, I., J. Fuger, R. J. M. Konings, R. J. Lemire, A. B. Muller, C. Nguyen-Trung, and H. Wanner. 1992. Chemical Thermodynamics of Uranium. North-Holland, Amsterdam.

Guillaumount, R., T. Fanghanet, V. Neck, J. Fuger, D. A. Palmer, I. Grenthe, and M. H. Rand. 2003. Update on the Chemical Thermodynamics of Uranium, Neptunium, Plutonium, Americium, and Technetium. Elsevier.

Hammersley, A. P. 1997. FIT2D: An Introduction and Overview, Internal Report ESRF97HA02T; European Synchrotron Radiation Facility, Grenoble, France.

Herbelin, A., and J. Westall. 1999. FITEQL: A Computer Program for Determination of Chemical Equilibrium Constants from Experimental Data, Version 4.0. Report 99-01. Oregon State University, Corvallis, OR. 
ICDD. 2003. JCPDS Powder Diffraction Files, PDF. International Centre for Diffraction Data (ICDD), Newtown, Square, PA.

Ilton, E. S., C. Liu, W. Yantasee, Z. Wang, D. Moore, and J. M. Zachara. 2005. The effect of carbonate on the dissolution of synthetic Na-boltwoodite. Geochimica et Cosmochimica Acta (Submitted).

Kukkadapu, R. K., J. M. Zachara, J. K. Fredrickson, and D. W. Kennedy. 2004. Biotransformation of two-line silica-ferrihydrite by a dissimilatory Fe(III)-reducing bacterium: Formation of carbonate green rust in the presence of phosphate. Geochim. Cosmochim. Acta, 68(13):2799-2814.

Lichtner, P. C. 2001. FLOTRAN: User's Manual. Report No. LA-UR-02-2349, Los Alamos National Laboratory, Los Alamos, New Mexico.

Lichtner, P. C. 2000. Critique of dual continuum formulations of multicomponent reactive transport in fractured porous media, dynamics of fluids in fractured rock. Geophys. Monograph, 122:281-298.

Liu, C., J. M. Zachara, W. Yantasee, P. D. Majors, and J. P. McKinley. 2006. Microscopic reactive diffusion of uranium in the contaminated sediments at Hanford, USA: Characterization and modeling. Water Resources Research (Submitted).

Liu, C., J. M. Zachara, O. Qafoku, J. P. McKinley, S. M. Heald, and Z. Wang. 2004. Dissolution of uranyl microprecipitates in subsurface sediments at Hanford Site, USA. Geochim. Cosmochim. Acta, 68(22):4519-4537.

Liu, C., J. M. Zachara, S. C. Smith, J. P. McKinley, and C. C. Ainsworth. 2003. Desorption kinetics of radiocesium from subsurface sediments at Hanford Site, USA. Geochim. Cosmochim. Acta, 67(16):28932912.

McKinley, J. P., J. M. Zachara, S. C. Smith, and C. Liu. 2006. Cation exchange reactions controlling desorption of 90Sr2+ from coarse-grained contaminated sediments from the Hanford formation, Washington. Geochimica et Cosmochimica Acta (Submitted).

McKinley, J. P., J. M. Zachara, C. Liu, and S. C. Heald. 2005. Precipitation of waste uranium as a uranyl silicate in microfractures. Geochimica et Cosmochimica Acta (In press).

McKinley, J. P., R. J. Serne, J. M. Zachara, C. J. Zeissler, and R. M. Lindstrom. 2001. The distribution and retention of 137Cs in sediments at the Hanford Site, Washington. Environ. Sci. Technol. 35:34333441.

Newville, M. 2001a. IFEFFIT: Interactive XAFS analysis and FEFF fitting. J. Synch. Rad., 8:322-324.

Newville, M. 2001b. EXAFS analysis using FEFF and FEFFIT. J. Synch. Rad., 8:96-100.

Qafoku, N. P., J. M. Zachara, C. Liu, P. L. Gassman, O. S. Qafoku, and S. C. Smith. 2005. Kinetic desorption and sorption of $\mathrm{U}(\mathrm{VI})$ during reactive transport in a contaminated Hanford sediment. Environ. Sci. Technol., 39:3157-3165. 
Rard, J. A., M. H. Rand, G. Anderegg, and H. Wanner. 1991. Chemical Thermodynamics of Technetium, Chapter 3; (M. C. A. Sandino and E. Osthols, eds.), Elsevier, The Netherlands, Amsterdam, pp. 544.

Toride, N., F. J. Leij, and M. T. van Genuchten. 1999. The CXTFIT Code for Estimating Transport Parameters from Laboratory or Field Tracer Experiments; U.S. Salinity Laboratory.

Turner, G. D., J. M. Zachara, J. P. McKinley, and S. C. Smith. 1996. Surface-charge properties and UO22+ adsorption of a subsurface smectite. Geochim. Cosmochim. Acta, 60:3399-3414.

Wang, Z., J. M. Zachara, P. L. Gassman, O. Qafoku, and J. Catalano. 2005a. Fluorescence spectroscopy of U(VI)-silicates and U(VI)-contaminated Hanford sediment. Geochim. Cosmochim. Acta, 69(6): 13911403.

Wang, Z., J. M. Zachara, J. P. McKinley, S. C. Smith, and S. M. Heald. 2005b. Cryogenic laser induced U(VI) fluorescence studies of a U(VI) substituted natural calcite: Implications to U(VI) speciation in contaminated Hanford sediments. Environ. Sci. Technol., 39:2651-2659.

Wang, Z., J. M. Zachara, W. Yantasee, P. L. Gassman, C. Liu, and A. G. Joly. 2004. Cryogenic laser induced fluorescence characterization of U(VI) in Hanford Vadose Zone pore waters. Environ. Sci. Technol., 38(21):5591-5597.

Webb, S. M. 2005. SIXPack: A graphical user interface for XAS analysis using IFEFFIT. Phys. Scr., T115, 1011-1014.

Zachara, J. M., S. C. Smith, C. Liu, J. P. McKinley, R. J. Serne, and P. L. Gassman. 2002. Sorption of $\mathrm{Cs}+$ to micaceous subsurface sediments from the Hanford site, USA. Geochim. Cosmochim. Acta, 66:193-211.

Zeissler, C. J., R. M. Lindstrom, and J. P. McKinley. 2001. Radioactive particle analysis by digital autoradiography. J. Radioanal. Nuclear Chem., 248(2):407-412. 


\section{Distribution}

No. of

\section{Copies}

\section{ONSITE}

\section{DOE Richland Operations Office}

* DOE Public Reading Room (2) H2-53

\section{Pacific Northwest National Laboratory}
C. C. Ainsworth
K6-96
J. E. Amonette
K8-96
L. R. Burns
K6-94
N. J. Fix
J2-56
J. S. Fruchter
K6-96
P. E. Long
K9-33
S. P. Luttrell
K6-96
J. P. McDonald
K6-96
L. F. Morasch
K8-86
T. G. Naymik
K6-96
R. M. Smith
K6-96
F. A. Spane
K6-96
D. L. Stewart
K6-96
J. E. Szecsody
K3-61
C. J. Thompson
K6-96
V. R. Vermeul
K6-96
* K. Waters-Husted (Project Files) K6-96
D. M. Wellman
K3-92
B. A. Williams
K6-81
M. D. Williams
K6-96
* Hanford Technical Library (2) P8-55

*Received printed hard copies. All others received electronic distribution. 